\begin{tabular}{|} 
Ambiente \& Água - An Interdisciplinary Journal of Applied Science \\
ISSN 1980-993X - doi:10.4136/1980-993X \\
www.ambi-agua.net \\
E-mail: ambi.agua@gmail.com
\end{tabular}

\title{
Spatial variability of soil erodibility in pastures and forest areas in the municipality of Porto Velho, Rondônia
}

\author{
ARTICLES doi:10.4136/ambi-agua.2750
}

Received: 12 May 2021; Accepted: 10 Nov. 2021

\begin{abstract}
Lucivânia Izidoro da Silva1 ${ }^{1 D}$; Milton César Costa Campos $^{2}{ }^{D}$; Wildson Benedito Mendes Brito ${ }^{3 *}$; José Maurício da Cunha ${ }^{4}$; Alan Ferreira Leite de $\operatorname{Lima}^{3}$; Luís Antônio Coutrim dos Santos ${ }^{5(D ;}$; Abdul Luís Hassane ${ }^{6}$
\end{abstract}

${ }^{1}$ Programa de Pós-Graduação em Agronomia Tropical. Universidade Federal do Amazonas (UFAM), Avenida General Rodrigo Otavio Jordao Ramos, n 1200, CEP: 69067-005, Manaus, AM, Brazil.

E-mail: lucy-vany@hotmail.com

${ }^{2}$ Instituto de Educação, Agricultura e Ambiente. Universidade Federal do Amazonas (UFAM), Rua 29 de Agosto, n 786, CEP: 69077-000, Manaus, AM, Brazil.

E-mail: mcesarsolos@gmail.com

${ }^{3}$ Faculdade de Ciências Agrárias. Universidade Federal do Amazonas (UFAM), Avenida General Rodrigo Otavio Jordao Ramos, $\mathrm{n}^{\circ}$ 1200, CEP: 69067-005, Manaus, AM, Brazil.

E-mail: ala_leite@hotmail.com

${ }^{4}$ Instituto de Educação, Agricultura e Ambiente. Universidade Federal do Amazonas (UFAM), Rua 29 de Agosto, ${ }^{\circ}$ 786, CEP: 69077-000, Manaus, AM, Brazil.

E-mail: maujmc@gmail.com

${ }^{5}$ Centro De Estudos Superiores De Itacoatiara. Universidade do Estado do Amazonas (UEA), Avenida Mário Andreazza, nº 2960, CEP: 69101-603, Itacoatiara, AM, Brazil.

E-mail: lacsantos@uea.edu.br

6Programa de Pós-Graduação em Ciências Ambientais, Doutorando em Geografia na Universidade Federal Rio Grande de Sul. Faculdade de Ciências e Tecnologia. Universidade Zambeze (UniZambeze), Avenida Alfredo Lawley, CP 369, Beira, Mozambique. E-mail: assaneluis@gmail.com

*Corresponding author. E-mail: wild.brito@gmail.com

\begin{abstract}
"Erodibility" is a characteristic of the soil that represents the susceptibility with which its particles from the most superficial layer are taken and transported to lower places by erosive agents, causing environmental and economic damages. This work estimated soil erodibility in pastures and forest areas in the municipality of Porto Velho-Rondônia. In the field, three areas with different types of vegetation were selected, one with brachiaria, another with mombaça grass, and a third in native forest. In areas with pastures, a sampling mesh of equal sizes was outlined $(90 \mathrm{~m} \times 60 \mathrm{~m})$, and in the forested area an approximate sampling mesh $(90 \mathrm{~m} \times 50 \mathrm{~m})$, with a regular spacing of $10 \mathrm{~m}$ between the samples points for both areas. The sampling was done at the crossing points of the mesh at a depth of 0.0-0.2 m, composing 70 sample points in the areas with pastures and 60 sample points in the forest area, totaling 200 samples. Then, laboratory analyzes were carried out to determine the texture followed by the fractionation of the sand, and the organic carbon followed by the estimate of the organic matter of the soil. The erodibility factors were calculated using indirect prediction models, and then, univariate, geostatistical and multivariate techniques were applied. The pastures' environments differed from the forest environment. However, the mombaça grass area functions as an intermediate environment between the forest and the brachiaria, being closer to the forest environment.
\end{abstract}


Keywords: erodibility, factors, kriging, principal components.

\section{Variabilidade espacial da erodibilidade do solo em áreas de pastagens e floresta no município de Porto Velho, Rondônia}

\section{RESUMO}

A erodibilidade é uma característica do solo que representa a susceptibilidade com que suas partículas da camada mais superficial são levadas e transportadas para locais mais baixos por agentes erosivos, causando danos ambientais e econômicos. O objetivo deste trabalho foi estimar a erodibilidade do solo em áreas de pastagens e florestas no município de Porto VelhoRondônia. Em campo, foram selecionadas três áreas com diferentes tipos de vegetação, uma com braquiária, outra com capim mombaça e uma terceira em floresta nativa. Nas áreas com pastagens, foi delineada uma malha amostral de tamanhos iguais $(90 \mathrm{~m} \mathrm{x} 60 \mathrm{~m})$, e na área de floresta uma malha amostral aproximada $(90 \mathrm{~m}$ x $50 \mathrm{~m})$, com espaçamento regular de $10 \mathrm{~m}$ entre os pontos amostrais para ambas as áreas. A amostragem foi realizada nos pontos de cruzamento da malha na profundidade de $0,0-0,2 \mathrm{~m}$, compondo 70 pontos amostrais nas áreas com pastagens e 60 pontos amostrais na área de floresta, totalizando 200 amostras. Em seguida, foram realizadas análises laboratoriais para determinação da textura seguida do fracionamento da areia, e do carbono orgânico seguida da estimativa da matéria orgânica do solo. Os fatores de erodibilidade foram calculados por meio de modelos de predição indireta e, em seguida, foram aplicadas técnicas univariadas, geoestatísticas e multivariadas. Os ambientes de pastagem diferiram do ambiente de floresta. No entanto, a área de capim mombaça funciona como um ambiente intermediário entre a floresta e a braquiária, estando mais próxima do ambiente de floresta.

Palavras-chave: componentes principais, fatores erodibilidade, krigagem.

\section{INTRODUCTION}

Soil erosion is a process of detachment and accelerated drag of soil particles caused by water (water erosion) or wind (wind erosion) (Demarchi et al., 2019). Erosion can be classified into: Geological or Natural erosion, which comes from natural phenomena that act continuously in the earth's crust for the benefit of the formation of the soil itself, being recognizable only over long periods of activity; and Accelerated or Anthropic erosion, which comes from the intensification of the natural erosive process due to the direct action of man on the soil-plantatmosphere system through the insertion of practices that destroy the balance of the natural conditions of this process (Bertoni and Lombardi Neto, 1999).

According to Morgan (1995), soil erosion is basically caused by the detachment and transport of soil particles by the action of water and wind. The ease with which this process occurs is called soil erodibility, being one of the most worrying factors within agriculture because it directly and indirectly affects the plantation and the environment, being the main cause of the decline in soil fertility, even more in regions where there is greater degradation of the most fertile soil layers (Macedo et al., 2010).

To solve this problem, several researchers have proposed indirect models for predicting soil losses (in the laboratory), which make it possible to consider the spatial and temporal variations of the conditioning factors of erosive processes. These models aim to assist in agricultural planning, to apply conservation techniques that reduce soil losses as much as possible, to minimize environmental and economic damage, and to improve soil quality (Amorim et al., 2010).

The most widely used indirect prediction model in soil science has been the K-factor of

Rev. Ambient. Água vol. 16 n. 6, e2750 - Taubaté 2021 
the Universal Soil Loss Equation (USLE), which expresses the soil's susceptibility to water erosion, capable of estimating soil losses from water erosion throughout the year. The $\mathrm{K}$ factor is important in estimating erosion losses, which is characterized by being a procedure for combining soil characteristics, which allows its assessment through the USLE (Marques et al., 1997; Sá et al., 2004).

Properly managed pasture systems improve soil properties, such as: water retention, aggregate stability, soil organic matter content and nutrient cycling (Franzluebbers et al., 2011). Soares et al. (2016) also found that pasture areas have high percentages of aggregates with larger diameters.

Several studies have applied multivariate statistics to investigations of soil variables in pasture areas (Soares et al., 2016; Assunção et al., 2019; Dias et al., 2019; Zenero et al., 2019). According to Sena et al. (2002), one of the advantages of this technique is the formation of groups of populations with similar characteristics, allowing a better understanding of the variations of the processes that occur in the soil.

Thus, analyzing the spatial variability of the soil, geostatistics has been used as a tool that allows the interpretation and projection of results based on the structure of its natural variability. In addition, it facilitates the understanding of the variability of properties, and of their influence on production, showing the best management alternatives (Silva Neto et al., 2012). Thus, the study estimated soil erodibility and spatial variation using geostatistical techniques in pasture and forest areas in the municipality of Porto Velho-Rondônia.

\section{MATERIAL AND METHODS}

\subsection{Location and characterization of the study area}

The study was carried out in the União Bandeirante District, located in the city of Porto Velho, Rondônia, Brazil. The geographical coordinates are latitude $9^{\circ} 45^{\prime} 32^{\prime \prime} \mathrm{S}$ and longitude 64'31'39" W (Figure 1), which represent three areas, two areas with pastures - brachiaria (Brachiaria brizantha cv. Marandu) and mombaça (Panicum maximum cv. Mombaça); and an area with native forest.

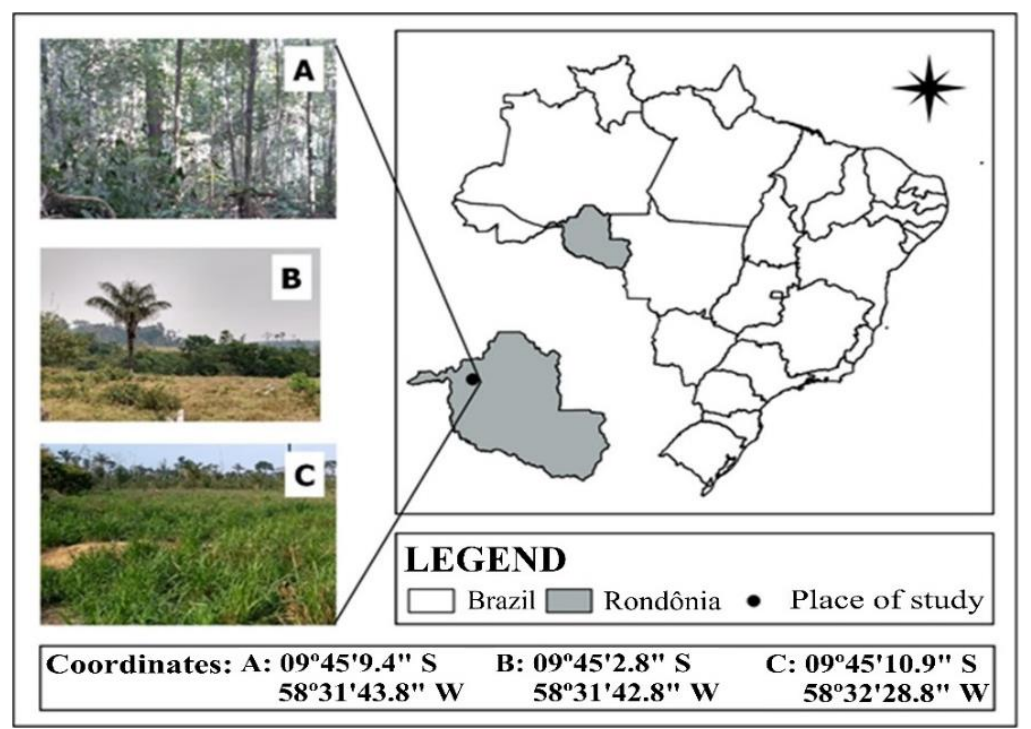

Figure 1. Location map of the study area: A: Forest, B: Brachiaria (Brachiaria brizantha cv. Marandu) and C: Mombaça (Panicum maximum cv. Mombaça), in the municipality of Porto Velho, RO.

The climate of the region belongs to Group A (Tropical Rainy Climate) and climate type Am (monsoon rains) according to the Köppen classification, presenting a short dry season 
between the months of June and September. The annual rainfall ranges from 2,500 to 2,800 $\mathrm{mm}$. The annual temperature is between 24 to $26^{\circ} \mathrm{C}$. The relative humidity is quite high, varying between 85 and $90 \%$ in the rainy season and between 60 to $70 \%$ in the dry season. The local relief is smooth and wavy with altitudes ranging from 100 to $200 \mathrm{~m}$ (Alvares et al., 2013).

The soils found are developed from undifferentiated sedimentary covers, associated with environments of alluvial fans, fluvial channels, flood plains and lakes, made up of sediments whose granulometry varies from gravel to clay, with significant lateritization (Adamy, 2010).

The predominant soils in Rondônia are the Latossolos, which occupy an area of around $58 \%$, being $26 \%$ of the Latossolo Vermelho Amarelo, $16 \%$ of the Latossolo Vermelho and $16 \%$ of the Latossolo Amarelo. Argissolos and Neossolos occupy $11 \%$ of the territory each, Cambissolos occupy $10 \%$ and Gleissolos occupy $9 \%$. The other soil classes occupy the rest of the area (12\%) (Schlindwein et al., 2012). The vegetation typology is called Dense Ombrophilous Forest (IBGE, 2004), composed of dense and multilayered trees between 25 and 30 meters high (Perigolo et al., 2017).

For implantation of pasture areas, deforestation was carried out with successive burning over time, aiming to facilitate the cleaning of areas for later sowing of forages. There are 110 animals raised in the area, which covers 44.28 ha. These animals are rotated every 45 days between paddocks with brachiaria and mombaça grass, using a paddock for each grazing area.

The area with brachiaria is 26.36 ha; it was planted in 2008 and remained unused for one year and was used infrequently until 2010, after which 4.5 animals/ha were used. The area with mombaça grass is $17.92 \mathrm{ha}$; it was introduced in 2007 and was left unused for three years, after which 6.14 animals/ha were used in the 45-day rotation between the brachiaria.

\subsection{Field methodology}

In the field, a $90 \mathrm{~m} \times 60 \mathrm{~m}$ mesh was established for both areas with brachiaria and mombaça grass, and $90 \mathrm{~m} \times 50 \mathrm{~m}$ for the forest area, with a regular spacing of $10 \mathrm{~m}$ between the sampling points for both areas. The crossing points of the meshes were georeferenced with GPS equipment (DATUM WGS 84) for the construction of the Digital Elevation Model (DEM). In each collection area, an altimetric survey was carried out (Figure 2).

The soil was collected at the crossing points of the meshes, at a depth of $0.0-0.2 \mathrm{~m}$, composing 60 sample points for the forest area and 70 points for each pasture area, totaling 200 samples. For each area, we collected soil clods $10 \mathrm{~cm}$ high. These samples were used to determine the organic carbon and the physical properties of the soil.

\subsection{Laboratory methodology}

The collected soil underwent a process of natural drying and breaking, then it was sieved in a $2 \mathrm{~mm}$ mesh, composing the Air-Dried Fine Earth (ADFE) necessary for the analysis of organic carbon (OC) and particle size (sand, silt and clay) following the methodology proposed by Teixeira et al. (2017).

Textural analysis of the soil was determined using the pipette method, with $\mathrm{NaOH}$ solution $1 \mathrm{~mol} \mathrm{~L}^{-1}$ as a chemical dispersant and mechanical agitation using the Wagner type agitator, in a slow rotation apparatus for 16 hours at $50 \mathrm{rpm}$.

The granulometric fractions of the sand obtained from the texture were sieved to determine the dimensions of its solid particles. Each sample was shaken for 3 minutes using a sieve pattern with the following meshes: $2 \mathrm{~mm}, 1 \mathrm{~mm}, 0.5 \mathrm{~mm}, 0.250 \mathrm{~mm}, 0.125 \mathrm{~mm}$ and $0.053 \mathrm{~mm}$. For this fractionation of the sand, a Sieve Agitator (Teixeira et al., 2017) model SOLOTEST was used, necessary to estimate the erodibility factors.

Organic carbon (OC) was determined by the Walkley-Black method (Walkley and Black, 1934), modified by Yeomans and Bremner (1988), in which the OC is oxidized with a mixture of potassium dichromate $0.0667 \mathrm{~mol} \mathrm{~L}^{-1}$ and titrated with ammoniacal ferrous sulphate 0.102 
mol L ${ }^{-1}$ in the presence of the diphenylamine indicator (1\%) (Teixeira et al., 2017). Considering that the OC contributes around 58\% in the composition of the humus, the organic matter (OM) of the soil was estimated by the expression: $\mathrm{OM}=\mathrm{OC} \times 1.724$.

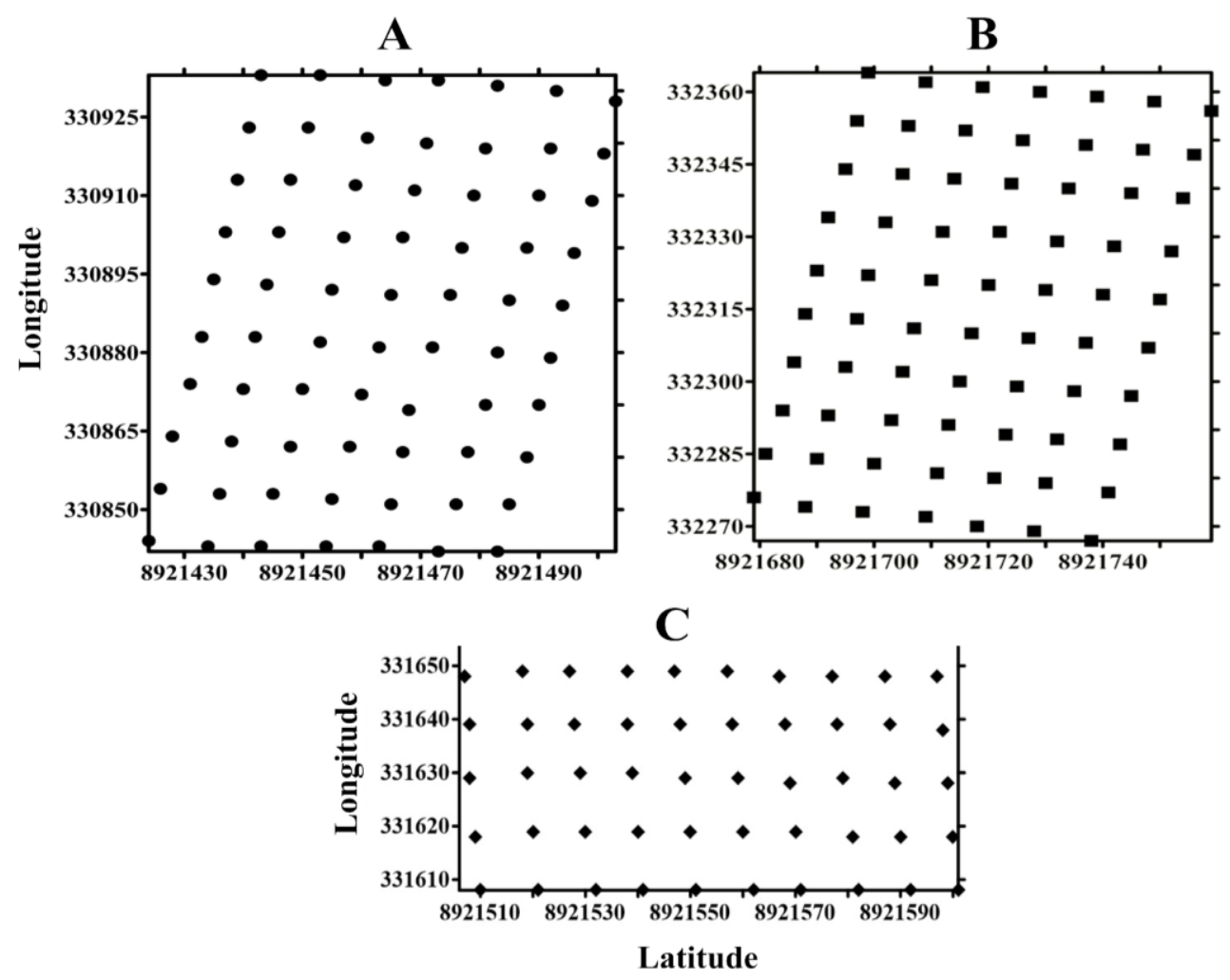

Figure 2. Meshes of the study area: A: Forest, B: Brachiaria (Brachiaria brizantha cv. Marandu) and C: Mombaça (Panicum maximum cv. Mombaça), in the municipality of Porto Velho, RO.

\subsection{Calculation of erodibility factors $\left(K, K_{i}, K_{r}\right)$ and shear stress $\left(\tau_{c}\right)$}

To estimate soil erodibility, indirect prediction models were used, which involve the values of soil attributes analyzed in the laboratory. Thus, in the present work, the USLE (Universal Soil Loss Equation) and the WEPP (Water Erosion Prediction Project) models were used to determine the conditioning factors of erosion in the study sites.

To calculate the global soil erodibility ( $\mathrm{K}$ factor, $\mathrm{t} \mathrm{ha}^{-1} \mathrm{MJ}^{-1} \mathrm{~mm}^{-1} \mathrm{ha}^{-1} \mathrm{~h}$ ), the method modified by Denardin (1990) was used to evaluate K factor in Brazilian soils, according to Equation 1.

$$
K=0.00000748 M+0.00448059 p-0.0631175 X 27+0.01039567 X 32
$$

Where:

$\mathbf{M}=$ new silt $\mathrm{x}$ (new silt + new sand);

$\mathbf{p}=$ permeability coded according to Wischmeier et al (1971);

$\mathbf{X 2 7}=[(0.002 \times$ clay, $\%)+(0.026 \times$ silt,$\%)+(0.075 \mathrm{x}$ very fine sand, $\%)+(0.175 \mathrm{x}$ fine sand, $\%)+(0.375 \times$ medium sand, $\%)+(0.75 \times$ coarse sand, $\%)+(1.5 \times$ very coarse sand, $\%)]$ / (clay, $\%+$ silt, $\%+$ sand, $\%$ );

$\mathbf{X 3 2}=$ new sand $\mathrm{x}(\mathrm{OM} / 100)$;

New silt $=$ silt + very fine sand, $\%$; 
New sand $=$ very coarse sand + coarse sand + medium sand + fine sand, $\%$.

To calculate the interrill erodibility $\left(\mathrm{K}_{\mathrm{i}}, \mathrm{kg} \mathrm{s} \mathrm{m}^{-4}\right)$, rill erodibility $\left(\mathrm{K}_{\mathrm{r}}, \mathrm{s} \mathrm{m}^{-1}\right)$, and the critical shear stress $\left(\tau_{c}, \mathrm{~N} \mathrm{~m}^{-2}\right)$, we use equations from the WEPP model proposed by Flanagan and Livingston (1995) (Equations 2, 3, 4, 5, 6 and 7).

$$
\begin{aligned}
& \mathbf{K}_{\mathbf{i} \text { wepp }}=2728000+192100 \text { VFS sand } \geq 30 \% \\
& \mathbf{K}_{\mathbf{i} \text { wepp }}=6054000-55130 \text { CLAY sand }<30 \% \\
& \mathbf{K}_{\mathbf{r} \text { wepp }}=0.00197+0.00030 \text { VFS }+0.03863 * \text { EXP }(-1.84 * \text { OM }) \text { sand } \geq 30 \% \\
& \mathbf{K}_{\mathbf{r} \text { wepp }}=0.0069+0.134 * \text { EXP }(-0.20 * \text { CLAY }) \text { sand }<30 \% \\
& \boldsymbol{\tau}_{\mathbf{c} \text { wepp }}=2.67+0.065 \text { CLAY }-0.058 \text { VFS sand } \geq 30 \% \\
& \boldsymbol{\tau}_{\mathbf{c} \text { wepp }}=3.5 \text { sand }<30 \%
\end{aligned}
$$

Where:

VFS = very fine sand, \%;

CLAY = clay percentage;

$\mathbf{O M}=$ soil organic matter, \%;

\subsection{Statistical analysis}

\subsubsection{Univariate and descriptive statistics}

After determining the texture, soil organic matter and erodibility factors, univariate statistics (ANOVA) were performed to compare means of the attributes individually by the Tukey test $(\mathrm{p}<0.05)$. Both descriptive statistics and ANOVA were performed using the SPSS 21.0 software (IBM, 2017), in which the values of mean, median, standard deviation, coefficient of variation, asymmetry and kurtosis were calculated. The hypotheses of normality of the data were verified by the Kolmogorov-Smirnov test, using the statistical software Statistica 7.0 (Statsoft, 2004).

The coefficient of variation (CV\%) was assessed according to the classification proposed by Warrick and Nielsen (1980), which classifies soil variables as: CV $<12 \%, 12<\mathrm{CV}<60 \%$, and $\mathrm{CV}>60 \%$ for low, medium and high variability, respectively.

\subsubsection{Multivariate analysis}

For multivariate analysis (MANOVA), a factor analysis extracted by the method of Principal Component Analysis (PCA) was performed to obtain a set of smaller linear combinations of soil attributes that preserve most of the data provided by the soil property (Silva et al., 2010). The PCA aimed to find statistical significance of the sets of soil attributes that most discriminate between the environments under study, obtaining an answer as to in which environments the attributes are more influenced by the anthropic action. In this way, the PC is allowed to evaluate at the same time qualitatively the interactions between soil attributes by standardizing the values of the attributes to mean equal to zero and variance equal to one.

The adequacy of the factor analysis was indicated by the Kaiser-Meyer-Olkin (KMO) measure, which assesses the simple and partial correlations of the variables, and by the Bartlett sphericity test, which accepts or rejects the equality between the correlation and identity 
matrices. The extraction of the factors was performed by the principal component analysis, incorporating the variables that presented commonality equal to or greater than five (5.0), as described by Mingoti (2007). However, the choice of the number of factors to be used was made by the Kaiser criterion (factors that have eigenvalues greater than 1.0), so that they reach an accumulated variance above $70 \%$ of the variance of the variables. In order to simplify the factor analysis, orthogonal rotation (varimax) was performed and represented in a factorial plane of the variables for the principal components (Burak et al., 2010).

\subsubsection{Geostatistical analysis}

Geostatistics was used to assess the spatial variability of the analyzed attributes. For this, it was necessary to know if there is spatial dependence or not on the attributes studied, verified through the graph of the semivariogram. The GS+7.0 software (Robertson, 2004) was used to adjust semivariograms, based on the presupposition of the stationary intrinsic hypothesis (Equation 8).

$\hat{\gamma}(h)=\frac{1}{2 N(h)} \sum_{i=1}^{N(h)}\left[Z\left(x_{i}\right)-Z\left(x_{i}+h\right)\right]^{2}$

Where:

$\gamma(\mathbf{h})=$ semivariance value for a distance $h$;

$\mathbf{N}(\mathbf{h})=$ number of pairs involved in calculating the semivariance;

$\mathbf{Z}\left(\mathbf{x}_{\mathbf{i}}\right)=$ value of attribute $Z$ in position $x_{i}$;

$\mathbf{Z}\left(\mathbf{x}_{\mathbf{i}}+\mathbf{h}\right)=$ value of attribute $Z$ separated by a distance $h$ from position $x_{i}$.

During the adjustment, the coefficients of determination $\left(\mathrm{R}^{2}\right)$ and cross-validation $(\mathrm{C}-\mathrm{V})$ served as the basis for choosing the best theoretical model for the semivariogram. From the choice of the model type (linear, spherical, gaussian, exponential), its parameters were defined (nugget effect $-C_{0}$, sill $-C_{0}+C$, and range $-a$ ).

To analyze the Degree of Spatial Dependence (DSD) of the attributes that presented a spatial dependence structure, the examination of the parameters of the semivariograms proposed by Cambardella et al. (1994) was used. Thus, the semivariograms that have: DSD $\leq$ $25 \%, 25 \%<\mathrm{DSD}<75 \%$, and DSD $>75 \%$ are considered as having strong, moderate and weak spatial dependence, respectively.

After geostatistical modeling, the data generated were interpolated using kriging in the Surfer software Version 13.0 (Golden Software Inc., 1999). Then, the individual semivariograms were scaled for all variables in each area studied, with the aim of reducing them to the same scale, facilitating the comparison of results from different areas (Ceddia et al., 2009).

The experimental semivariograms were scaled by dividing the semi variances by the statistical variance (Guimarães, 1993). Thus, the choice of the scaled semivariogram model that best fitted the data was performed based on the determination coefficient $\left(\mathrm{R}^{2}\right)$, cross-validation $(\mathrm{C}-\mathrm{V})$, in addition to the practical knowledge of the behavior of the attributes in the environments.

\section{RESULTS}

Evaluating the dispersion of the variables (Table 1), it was observed in the pasture areas (brachiaria and mombaça) in comparison with the forest area, that the measures of central tendency (mean and median) of the variables presented symmetrical distribution, and both 
showed values very close for all attributes, which justifies normal or approximately normal distributions of the analyzed data.

Table 1. Descriptive statistics of texture, organic matter and soil erodibility factors in pasture and forest areas in the city of Porto Velho, RO.

\begin{tabular}{|c|c|c|c|c|c|c|c|}
\hline Properties & Mean & Median & Asymmetry & Kurtosis & ${ }^{1}$ S.D. & ${ }^{2} \mathrm{CV} \%$ & ${ }^{3} \mathrm{~K}-\mathrm{S}$ \\
\hline & \multicolumn{7}{|c|}{ Native Forest area } \\
\hline Sand $(\%)$ & $50.67 \mathbf{c}$ & 50.85 & -0.03 & -0.93 & 2.55 & 5.03 & $0.08 *$ \\
\hline Silt (\%) & $5.66 \mathbf{a}$ & 5.70 & -0.06 & -0.90 & 1.88 & 33.27 & $0.08^{*}$ \\
\hline Clay $(\%)$ & $42.68 \mathbf{a}$ & 42.74 & -0.14 & -0.69 & 3.00 & 7.03 & $0.09 *$ \\
\hline${ }^{4} \mathrm{OM}\left(\mathrm{g} \cdot \mathrm{kg}^{-1}\right)$ & $36.10 \mathbf{a}$ & 35.46 & 0.55 & 0.21 & 4.85 & 13.43 & $0.06^{*}$ \\
\hline${ }^{5}$ Factor K & $0.03 \mathbf{a}$ & 0.03 & 0.13 & -0.48 & 0.00 & 8.65 & $0.08^{*}$ \\
\hline${ }^{6} \mathrm{~K}_{\mathrm{i} \text { wepp }}$ & $3.42 \mathrm{E}^{6} \mathbf{b}$ & $3.38 \mathrm{E}^{6}$ & 0.17 & -1.35 & $2.08 \mathrm{E}^{5}$ & 6.08 & $0.13^{*}$ \\
\hline${ }^{7} \mathrm{~K}_{\mathrm{r} \text { wepp }}$ & $0.0032 \mathbf{b}$ & 0.00 & 0.11 & -1.24 & 0.00 & 10.66 & $0.13^{*}$ \\
\hline \multirow[t]{2}{*}{${ }^{8} \tau_{\text {c wepp }}$} & $5.29 \mathbf{a}$ & 5.28 & 0.07 & -0.61 & 0.23 & 4.27 & $0.06^{*}$ \\
\hline & \multicolumn{7}{|c|}{ Brachiaria area } \\
\hline Sand $(\%)$ & $66.83 a$ & 67.24 & -0.24 & -1.06 & 2.64 & 3.95 & $0.10^{*}$ \\
\hline Silt $(\%)$ & $2.95 \mathrm{c}$ & 2.86 & 0.18 & -0.90 & 0.89 & 30.07 & $0.06^{*}$ \\
\hline Clay $(\%)$ & $30.11 \mathbf{a}$ & 29.92 & 0.12 & -0.96 & 2.53 & 8.41 & $0.09 *$ \\
\hline${ }^{4} \mathrm{OM}\left(\mathrm{g} \cdot \mathrm{kg}^{-1}\right)$ & $25.65 b$ & 25.85 & -0.01 & -0.55 & 3.93 & 15.33 & $0.05^{*}$ \\
\hline${ }^{5}$ Factor K & $0.01 \mathbf{c}$ & 0.02 & 0.45 & -0.14 & 0.00 & 13.56 & $0.09 *$ \\
\hline${ }^{6} \mathrm{~K}_{\mathrm{i} \text { wepp }}$ & $3.80 \mathrm{E}^{6} \mathbf{a}$ & $3.81 \mathrm{E}^{6}$ & 0.02 & -1.39 & $3.51 \mathrm{E}^{5}$ & 9.23 & $0.13^{*}$ \\
\hline${ }^{7} \mathrm{~K}_{\mathrm{r} \text { wepp }}$ & $0.0042 \mathbf{a}$ & 0.00 & 0.00 & -1.00 & 0.00 & 15.83 & $0.08^{*}$ \\
\hline \multirow[t]{2}{*}{${ }^{8} \tau_{\text {c wepp }}$} & $4.32 \mathbf{c}$ & 4.30 & 0.36 & -0.53 & 0.22 & 4.99 & $0.07 *$ \\
\hline & \multicolumn{7}{|c|}{ Mombaça area } \\
\hline Sand $(\%)$ & $56.28 \mathrm{~b}$ & 56.65 & -0.45 & 0.57 & 3.61 & 6.41 & $0.13^{*}$ \\
\hline Silt (\%) & $4.45 \mathbf{b}$ & 4.48 & 0.62 & 0.31 & 1.36 & 30.55 & $0.10^{*}$ \\
\hline Clay (\%) & $39.27 \mathbf{b}$ & 38.83 & 0.62 & 0.30 & 3.53 & 9.00 & $0.13^{*}$ \\
\hline${ }^{4} \mathrm{OM}\left(\mathrm{g} \cdot \mathrm{kg}^{-1}\right)$ & $28.43 \mathbf{b}$ & 27.23 & 1.02 & 1.44 & 6.30 & 22.16 & $0.12^{*}$ \\
\hline${ }^{5}$ Factor K & $0.02 \mathbf{b}$ & 0.02 & 0.80 & 1.53 & 0.00 & 15.18 & $0.07 *$ \\
\hline${ }^{6} \mathrm{~K}_{\mathrm{i} \text { wepp }}$ & $3.23 \mathrm{E}^{6} \mathrm{c}$ & $3.19 \mathrm{E}^{6}$ & 0.35 & -0.68 & $2.34 \mathrm{E}^{5}$ & 7.26 & $0.07 *$ \\
\hline${ }^{7} \mathrm{~K}_{\mathrm{r} \text { wepp }}$ & $0.0031 \mathbf{b}$ & 0.00 & 0.90 & 1.92 & 0.00 & 16.90 & $0.09^{*}$ \\
\hline${ }^{8} \tau_{\text {c wepp }}$ & $5.07 \mathbf{b}$ & 5.02 & 0.60 & -0.03 & 0.26 & 5.11 & $0.10^{*}$ \\
\hline
\end{tabular}

Means followed by equal letters in the column do not differ by Tukey's test at the $5 \%$ probability level. ${ }^{1}$ S.D.: standard deviation; ${ }^{2} \mathrm{CV} \%$ : coefficient of variation, \%; ${ }^{3} \mathrm{~K}-\mathrm{S}$ : normality test (Kolmogorov-Smirnov significant at $5 \%$ probability); ${ }^{4} \mathrm{OM}$ : organic matter; ${ }^{5} \mathrm{~K}$ : soil erodibility, t.ha ${ }^{-1} \cdot \mathrm{MJ}^{-1} \cdot \mathrm{mm}^{-1}$.ha.h; ${ }^{6} \mathrm{~K}_{\mathrm{i} \text { wepp}}$ : interrill erodibility, kg.s.m ${ }^{-4}$; ${ }^{7} \mathrm{~K}_{\mathrm{r} \text { wepp}}$ : rill erodibility, $\mathrm{kg} . \mathrm{N}^{-1} \cdot \mathrm{s}^{-1} ;{ }^{8} \tau_{\mathrm{c} \text { wepp }}$ : critical shear stress, N.m ${ }^{-2}$.

It was noted through the texture results that the average values in the forest area indicate that this area has more clay, more organic matter and higher values of $K$ and $\tau_{c \text { wepp }}$ than in the areas with pastures.

Thus, the asymmetry values ranged from -0.45 to 1.02 , where variables with values greater than zero represent data with an asymmetric distribution on the right while the negatives indicate that they have an asymmetric distribution on the left. For kurtosis, values from -0.03 to 1.92 were observed; these values should preferably be null; however, values between -2 to +2 are acceptable (Negreiros Neto et al., 2014).

In the mombaça grass area, it was found that the standard deviation values were high, highlighting the value of $6.30 \mathrm{~g} . \mathrm{kg}^{-1}$ for organic matter $(\mathrm{OM})$. For the forest area, the OM presented a standard deviation value equal to $4.85 \mathrm{~g}_{\mathrm{kg}} \mathrm{kg}^{-1}$ and the lowest value found for the 
brachiaria area $\left(3.93 \mathrm{~g} \cdot \mathrm{kg}^{-1}\right)$.

Through the classification of the variation coefficient (CV\%) proposed by Warrick and Nielsen (1980), it was found that the highest value was found in the forest area $(33.27 \%)$, followed by the mombaça grass area $(30.55 \%)$ and brachiaria $(30.07 \%$,), all for the variable silt, being classified as medium variability of the data. The variable with the least variability was sand, with a value of $3.95 \%$ in the brachiaria area.

In general, the $\mathrm{K}$ factor for all areas showed normal hypothetical data distribution using the Kolmogorov-Smirnov test at $5 \%$ probability. Thus, the erodibility factors $\mathrm{K}, \mathrm{K}_{\mathrm{i}}$ wepp and $\tau_{\mathrm{c}}$ wepp showed low variability for the forest area, indicating a good homogeneity of the area, in addition to a good representativeness of the samplings performed.

However, the $\mathrm{K}$ factor $\left(\mathrm{t} \mathrm{ha}^{-1} \mathrm{MJ}^{-1} \mathrm{~mm}^{-1}\right.$ ha $\left.\mathrm{h}\right)$ was lower in the brachiaria area $(0.01)$, and a higher value was observed in the forest area (0.03), as in Table 1. Thus, the high value in the forest area may be related to the high content of OM present, which does not match the types of soils for which USLE was developed and adapted.

Table 2 shows the parameters of the adjusted semivariograms that best describe the spatial distribution of the analyzed attributes. It was confirmed that in the forest area, the attributes have a spatial dependence structure with a moderate degree for sand $(27.70 \%)$ and with a strong spatial dependence for all other attributes (DSD < 25\%). Some variables showed a condition of

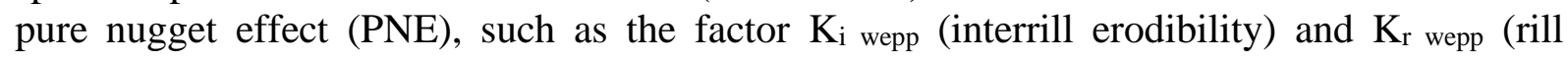
erodibility), that is, they did not show a spatial dependence structure.

On the other hand, in the brachiaria area the variable $\tau_{\mathrm{c} \text { wepp }}$ showed moderate spatial dependence, with a value of $28.10 \%$ and the other variables a strong spatial dependence (DSD $<25 \%$ ). In the mombaça area, it is observed that the variables sand, clay and organic matter showed strong DSD, with moderate DSD for the other variables, showing that possibly the mombaça grass area is more influenced by the intrinsic properties of the soil linked to the formation factors (Cambardella et al., 1994).

Table 2. Models and parameters estimated for semivariograms, under 0.0-0.2 m layer, in forest and pasture areas in the municipality of Porto Velho, RO.

\begin{tabular}{|c|c|c|c|c|c|c|c|c|c|c|c|c|c|c|c|c|c|c|}
\hline \multirow[t]{2}{*}{$\begin{array}{l}\text { Attri } \\
\text { bute }\end{array}$} & \multicolumn{6}{|c|}{ Forest } & \multicolumn{6}{|c|}{ Brachiaria } & \multicolumn{6}{|c|}{ Mombaça } \\
\hline & $\begin{array}{l}\text { Mo } \\
\text { d. }\end{array}$ & $\mathrm{C}_{0}$ & $\begin{array}{l}\mathrm{C}_{0+} \\
\mathrm{C}_{1}\end{array}$ & $\begin{array}{c}\mathrm{a} \\
(\mathrm{m})\end{array}$ & $\mathrm{R}^{2}$ & $\begin{array}{l}\text { DS } \\
\text { D\% }\end{array}$ & $\begin{array}{l}\text { Mo } \\
\text { d. }\end{array}$ & $\mathrm{C}_{0}$ & $\begin{array}{l}\mathrm{C}_{0+}+ \\
\mathrm{C}_{1}\end{array}$ & $\begin{array}{c}\mathrm{a} \\
(\mathrm{m})\end{array}$ & $\mathrm{R}^{2}$ & $\begin{array}{l}\text { DS } \\
\text { D\% }\end{array}$ & $\begin{array}{l}\text { Mo } \\
\text { d. }\end{array}$ & $\mathrm{C}_{0}$ & $\begin{array}{c}\mathrm{C}_{0}+ \\
\mathrm{C}_{1}\end{array}$ & $\begin{array}{c}\mathrm{a} \\
(\mathrm{m})\end{array}$ & $\mathrm{R}^{2}$ & $\begin{array}{l}\text { DS } \\
\text { D\% }\end{array}$ \\
\hline Sand & $\begin{array}{l}\text { Ex } \\
\text { p. }\end{array}$ & $\begin{array}{l}3 . \\
68\end{array}$ & $\begin{array}{l}13 . \\
28\end{array}$ & $\begin{array}{l}79 . \\
29\end{array}$ & $\begin{array}{l}0 . \\
92\end{array}$ & $\begin{array}{c}27.7 \\
0\end{array}$ & $\begin{array}{l}\mathrm{Ga} \\
\mathrm{u} .\end{array}$ & $\begin{array}{l}2 . \\
31\end{array}$ & $\begin{array}{l}18 . \\
94\end{array}$ & $\begin{array}{l}89 . \\
21\end{array}$ & $\begin{array}{l}0 . \\
98\end{array}$ & $\begin{array}{c}12.2 \\
0\end{array}$ & $\begin{array}{c}\text { Ex } \\
\text { p. }\end{array}$ & $\begin{array}{l}1 . \\
85\end{array}$ & $\begin{array}{l}16 . \\
02\end{array}$ & $\begin{array}{c}72 . \\
00\end{array}$ & 0. & $\begin{array}{c}11.5 \\
0\end{array}$ \\
\hline Silt & $\begin{array}{l}\text { Ex } \\
\text { p. }\end{array}$ & $\begin{array}{c}0 . \\
83\end{array}$ & $\begin{array}{c}6.1 \\
8\end{array}$ & 25. & $\begin{array}{l}0 . \\
85\end{array}$ & $\begin{array}{c}13.4 \\
0\end{array}$ & Lin & - & - & - & - & $\begin{array}{c}\text { PN } \\
\text { E }\end{array}$ & $\begin{array}{l}\text { Ex } \\
\text { p. }\end{array}$ & $\begin{array}{l}0 . \\
46\end{array}$ & $\begin{array}{c}1.3 \\
0\end{array}$ & $\begin{array}{l}27 . \\
60\end{array}$ & $\begin{array}{l}0 . \\
81\end{array}$ & $\begin{array}{c}35.5 \\
0\end{array}$ \\
\hline Clay & $\begin{array}{l}\text { Ex } \\
\text { p. }\end{array}$ & $\begin{array}{l}0 . \\
01\end{array}$ & $\begin{array}{c}14 . \\
51\end{array}$ & $\begin{array}{c}40 . \\
50\end{array}$ & $\begin{array}{l}0 . \\
90\end{array}$ & 0.10 & $\begin{array}{l}\text { Ex } \\
\text { p. }\end{array}$ & $\begin{array}{c}0 . \\
10\end{array}$ & $\begin{array}{l}14 . \\
89\end{array}$ & $\begin{array}{c}90 . \\
00\end{array}$ & $\begin{array}{c}0 . \\
90\end{array}$ & 0.70 & $\begin{array}{l}\text { Ex } \\
\text { p. }\end{array}$ & $\begin{array}{l}2 . \\
52\end{array}$ & $\begin{array}{l}17 . \\
26\end{array}$ & $\begin{array}{c}90 . \\
00\end{array}$ & $\begin{array}{c}0 . \\
90\end{array}$ & $\begin{array}{c}14.6 \\
0\end{array}$ \\
\hline $\mathrm{OM}$ & $\begin{array}{l}\text { Sp } \\
\text { h. }\end{array}$ & $\begin{array}{c}0 . \\
02\end{array}$ & $\begin{array}{l}32 . \\
54\end{array}$ & $\begin{array}{l}22 . \\
80\end{array}$ & $\begin{array}{l}0 . \\
80\end{array}$ & 0.60 & $\begin{array}{l}\text { Sp } \\
\text { h. }\end{array}$ & $\begin{array}{c}0 . \\
01\end{array}$ & $\begin{array}{l}15 . \\
03\end{array}$ & $\begin{array}{c}20 . \\
69\end{array}$ & $\begin{array}{l}0 . \\
71\end{array}$ & 0.00 & $\begin{array}{l}\text { Sp } \\
\text { h. }\end{array}$ & $\begin{array}{l}7 . \\
52\end{array}$ & $\begin{array}{l}30 . \\
07\end{array}$ & $\begin{array}{l}17 . \\
60\end{array}$ & $\begin{array}{c}0 . \\
71\end{array}$ & $\begin{array}{c}25.0 \\
0\end{array}$ \\
\hline $\begin{array}{c}\mathrm{K} \\
\text { Factor }\end{array}$ & $\begin{array}{c}\text { Ex } \\
\text { p. }\end{array}$ & $\begin{array}{c}0 . \\
00\end{array}$ & $\begin{array}{c}0.0 \\
0\end{array}$ & $\begin{array}{c}32 . \\
40\end{array}$ & $\begin{array}{l}0 . \\
77\end{array}$ & 0.00 & $\begin{array}{l}\text { Ex } \\
\text { p. }\end{array}$ & $\begin{array}{c}0 . \\
00\end{array}$ & $\begin{array}{c}0.0 \\
0\end{array}$ & $\begin{array}{l}39 . \\
90\end{array}$ & $\begin{array}{l}0 . \\
71\end{array}$ & 0.00 & $\begin{array}{c}\text { Ex } \\
\text { p. }\end{array}$ & $\begin{array}{c}0 . \\
00\end{array}$ & $\begin{array}{c}0.0 \\
0\end{array}$ & $\begin{array}{l}27 . \\
84\end{array}$ & $\begin{array}{l}0 . \\
70\end{array}$ & $\begin{array}{c}37.5 \\
0\end{array}$ \\
\hline $\mathrm{K}_{\mathrm{i} \text { wepp }}$ & Lin & - & - & - & - & $\begin{array}{c}\text { PN } \\
\text { E }\end{array}$ & Lin & - & - & - & - & $\begin{array}{c}\text { PN } \\
\text { E }\end{array}$ & Lin & - & - & - & - & $\begin{array}{c}\text { PN } \\
\text { E }\end{array}$ \\
\hline $\mathrm{K}_{\mathrm{r} \text { wepp }}$ & Lin & - & - & - & - & $\begin{array}{c}\text { PN } \\
\text { E }\end{array}$ & Lin & - & - & - & - & $\begin{array}{c}\text { PN } \\
\text { E }\end{array}$ & Lin & - & - & - & - & $\begin{array}{c}\text { PN } \\
\text { E }\end{array}$ \\
\hline$\tau_{\mathrm{c} \text { wepp }}$ & $\begin{array}{l}\text { Ex } \\
\text { p. }\end{array}$ & $\begin{array}{c}0 . \\
01\end{array}$ & $\begin{array}{c}0.0 \\
8 \\
\end{array}$ & $\begin{array}{c}48 . \\
00 \\
\end{array}$ & $\begin{array}{l}0 . \\
81\end{array}$ & $\begin{array}{c}15.4 \\
0 \\
\end{array}$ & $\begin{array}{l}\text { Ex } \\
\text { p. }\end{array}$ & $\begin{array}{c}0 . \\
03\end{array}$ & $\begin{array}{c}0.0 \\
3 \\
\end{array}$ & $\begin{array}{l}86 . \\
78 \\
\end{array}$ & $\begin{array}{l}0 . \\
95 \\
\end{array}$ & $\begin{array}{c}28.1 \\
0 \\
\end{array}$ & $\begin{array}{l}\text { Ex } \\
\text { p. }\end{array}$ & $\begin{array}{c}0 . \\
02\end{array}$ & $\begin{array}{c}0.0 \\
8 \\
\end{array}$ & $\begin{array}{c}86 . \\
40 \\
\end{array}$ & $\begin{array}{c}0 . \\
86 \\
\end{array}$ & $\begin{array}{c}28.4 \\
0 \\
\end{array}$ \\
\hline
\end{tabular}

Mod.: Model; Sph.: Spherical; Exp.: Exponential; Lin.: Linear; Gau.: Gaussian; $C_{0}$ : Nugget effect; $\mathrm{C}_{0}+\mathrm{C}_{1}$ : Sill; a: Range; $\mathrm{R}^{2}$ : Coefficient of determination; DSD\%: Degree of Spatial Dependence; OM: Organic Matter; PNE: Pure Nugget Effect; K: Erodibility of the soil; $\mathrm{K}_{\mathrm{i} \text { wepp }}$ : interrill erodibility; $\mathrm{K}_{\mathrm{r} \text { wepp: }}$ : rill erodibility; $\tau_{\mathrm{c} \text { wepp: }}$ critical shear stress.

The adjustments of the experimental semivariograms, kriging maps and spatial dependence analysis are shown in Figures 3, 4, 5, 6, 7 and 8, for the forest, brachiaria and mombaça grass areas. 

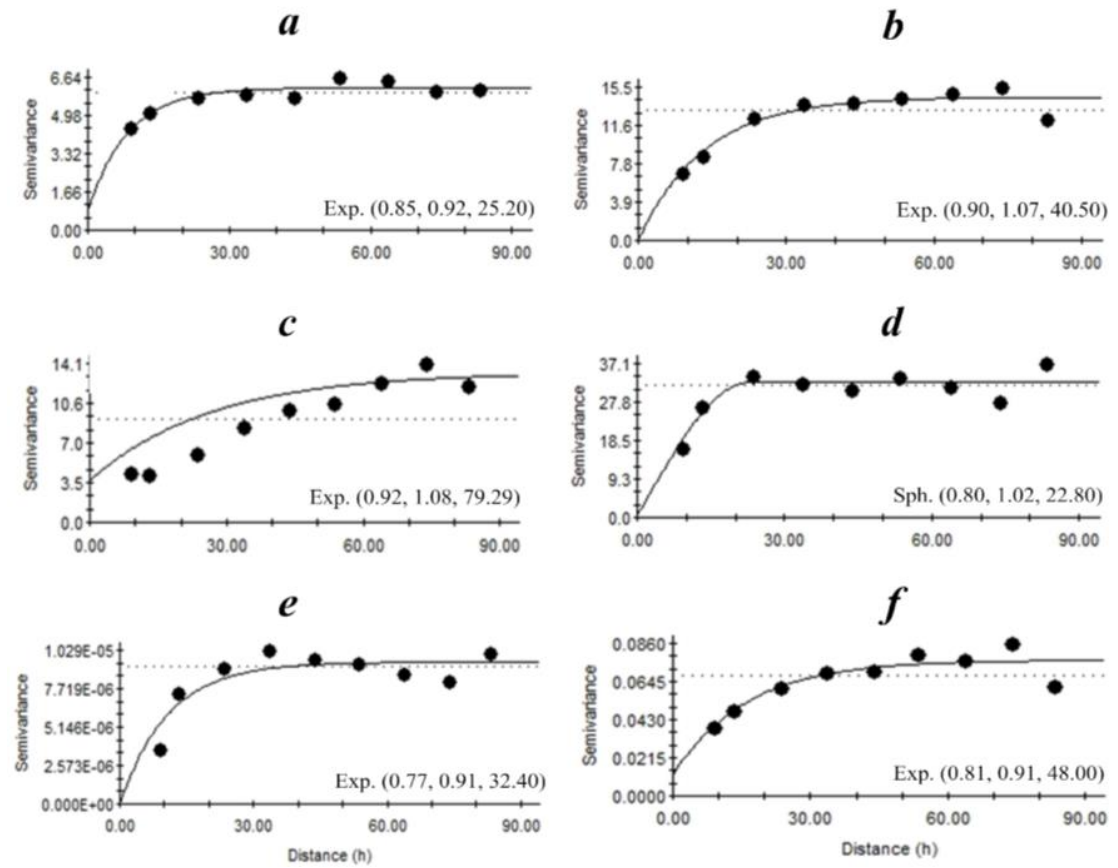

Figure 3. Experimental semivariograms adjusted for erodibility factors at a depth of $0.0-0.2 \mathrm{~m}$, in a forest area in the municipality of Porto Velho, RO. The letters represent the attributes: silt $(a)$, clay $(b)$, sand $(c)$, OM $(d), \mathrm{K}$ factor $(e)$ and shear stress $(f)$. The values in parentheses represent, respectively: coefficient of determination $\left(\mathrm{R}^{2}\right)$, crossvalidation $(\mathrm{C}-\mathrm{V})$ and range $(a)$.

$g$
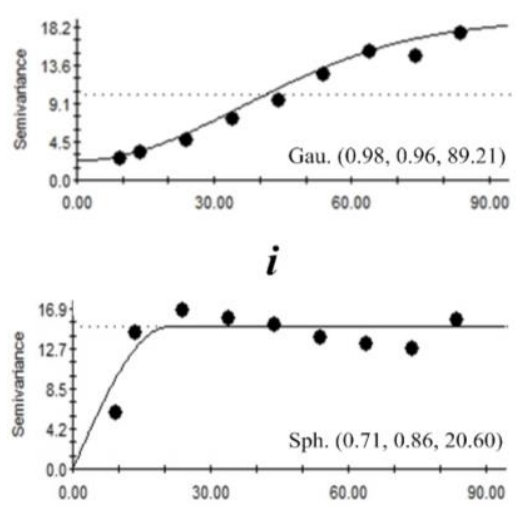
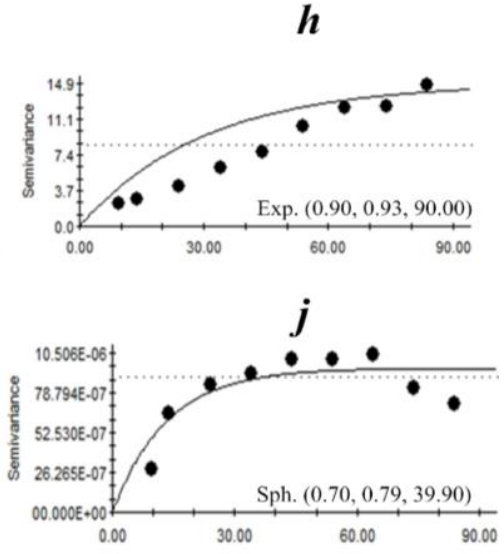

$\boldsymbol{k}$

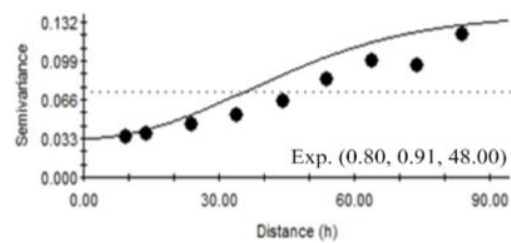

Figure 4. Experimental semivariograms adjusted for erodibility factors at a depth of $0.0-0.2 \mathrm{~m}$, in a brachiaria area in the municipality of Porto Velho, RO. The letters represent the attributes: sand $(g)$, clay $(h), \mathrm{OM}(i), \mathrm{K}$ factor $(j)$ and shear stress $(k)$. The values in parentheses represent, respectively: coefficient of determination $\left(\mathrm{R}^{2}\right)$, cross-validation $(\mathrm{C}-\mathrm{V})$ and range $(a)$. 

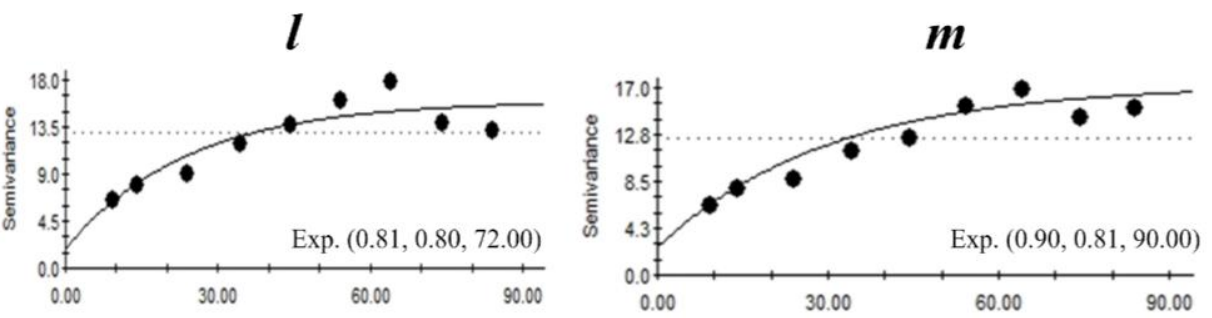

n
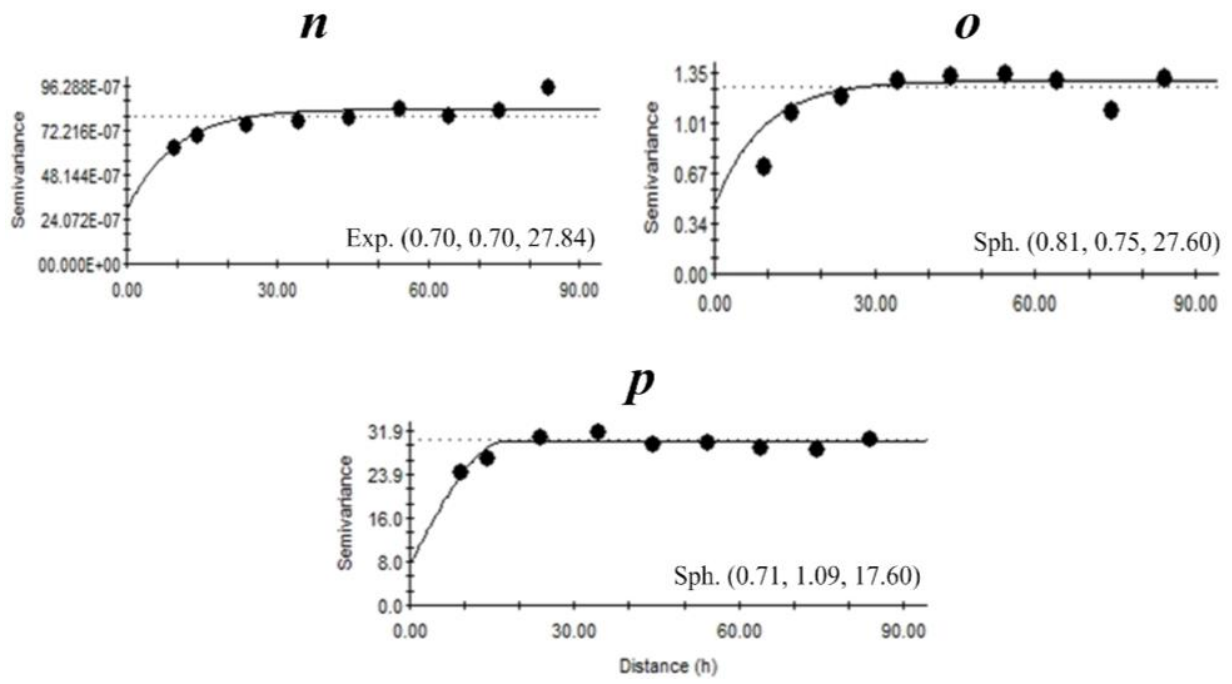

Figure 5. Experimental semivariograms adjusted for erodibility factors at a depth of 0.0-0.2 m, in a mombaça grass area in the municipality of Porto Velho, RO. The letters represent the attributes: sand $(l)$, clay $(m), \mathrm{K}$ factor $(n)$, silt $(o)$, and $\mathrm{OM}(p)$. The values in parentheses represent, respectively: coefficient of determination $\left(\mathrm{R}^{2}\right)$, cross-validation $(\mathrm{C}-\mathrm{V})$ and range $(a)$.
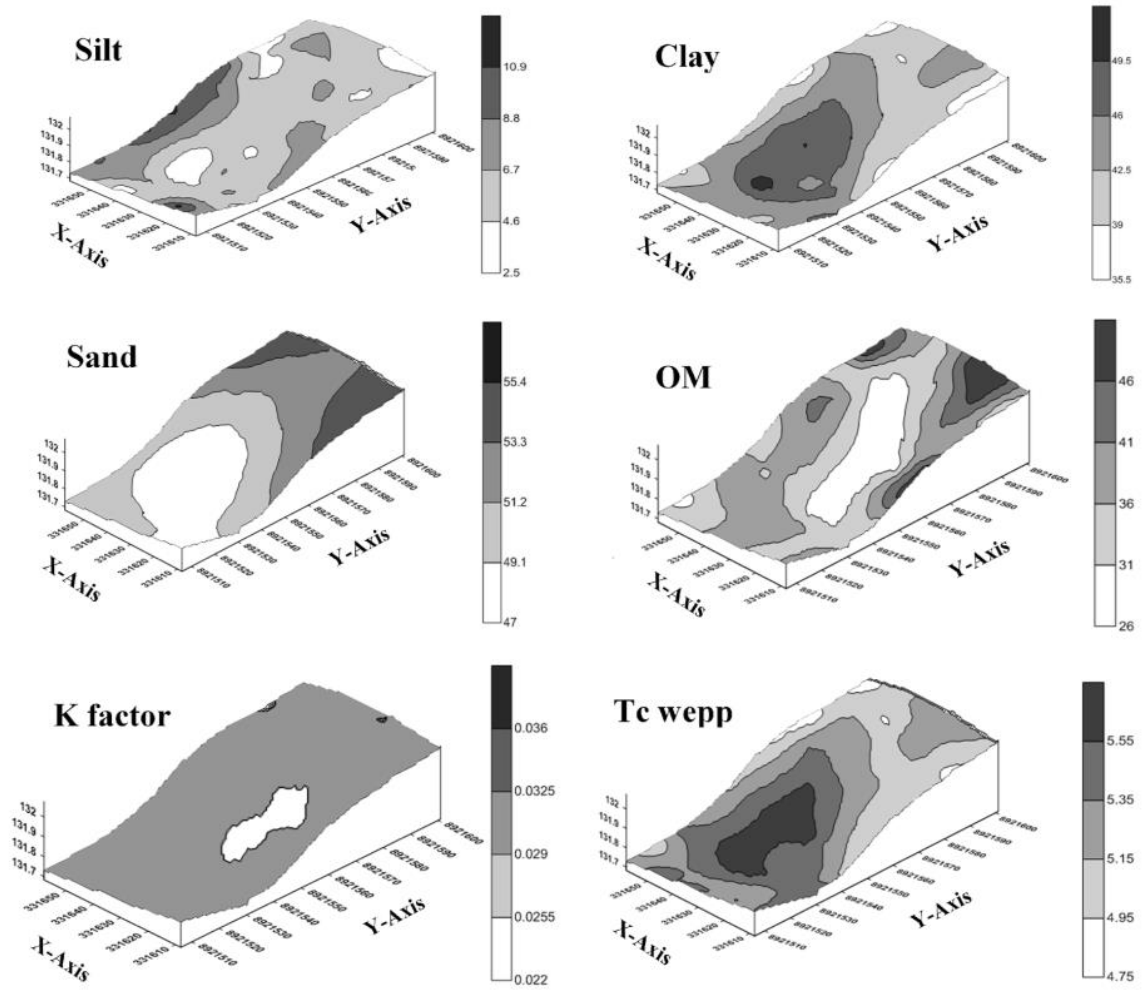

Figure 6. Kriging maps of soil attributes and erodibility factors in a native forest area in the municipality of Porto Velho, RO. 

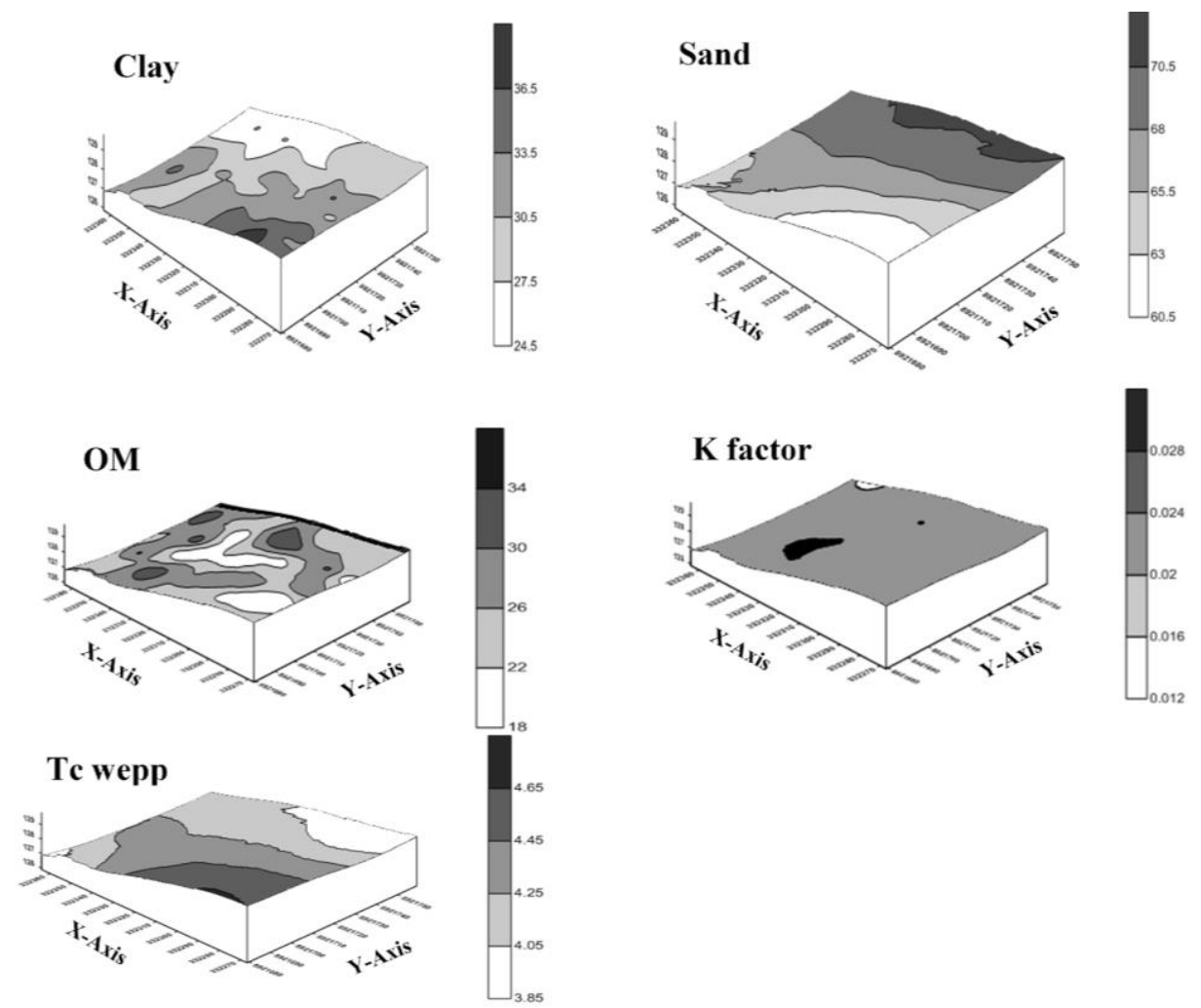

Figure 7. Kriging maps of soil attributes and erodibility factors in a brachiaria area in the municipality of Porto Velho, RO.
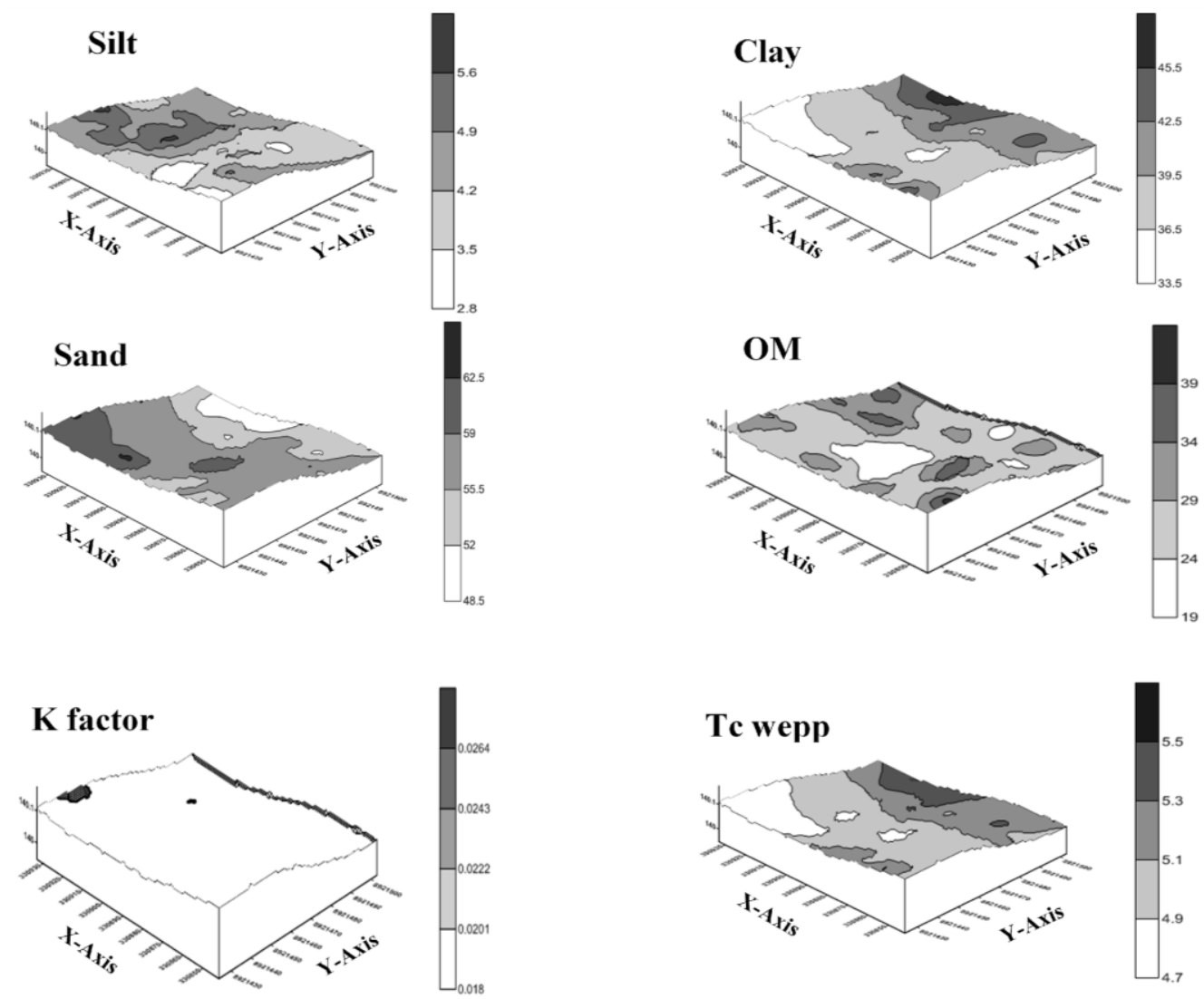

Figure 8. Kriging maps of soil attributes and erodibility factors in a mombaça area in the municipality of Porto Velho, RO. 
Through the results, it was possible to observe that the attributes showed spatial dependence, adjusting predominantly to the exponential and spherical models with values of $\mathrm{R}^{2}$ above 0.70 for all areas.

Oliveira et al. (2015a), studying soils in Amazonas, observed the predominance of the spherical model in forest area and exponential model in pastures to the adjustment of semivariograms for soil attributes.

The coefficient of determination showed values ranging from 0.71 to 0.98 while crossvalidation varied from 0.71 to 1.00 for all areas. According to Azevedo (2004), the more the $\mathrm{R}^{2}$ is close to 1.00 , the better the estimation of the values by the common kriging method.

The scaled semivariograms for the three areas studied are shown in Figure 9. The model adjusted to the graphs is exponential for the three areas, which showed $\mathrm{R}^{2}$ performance between 0.57 to 0.69 and cross-validation between 0.76 to 0.83 . Oliveira et al. (2015b) also observed that, in forest and pastures areas, the exponential model fits better for the chemical attributes of the soil.
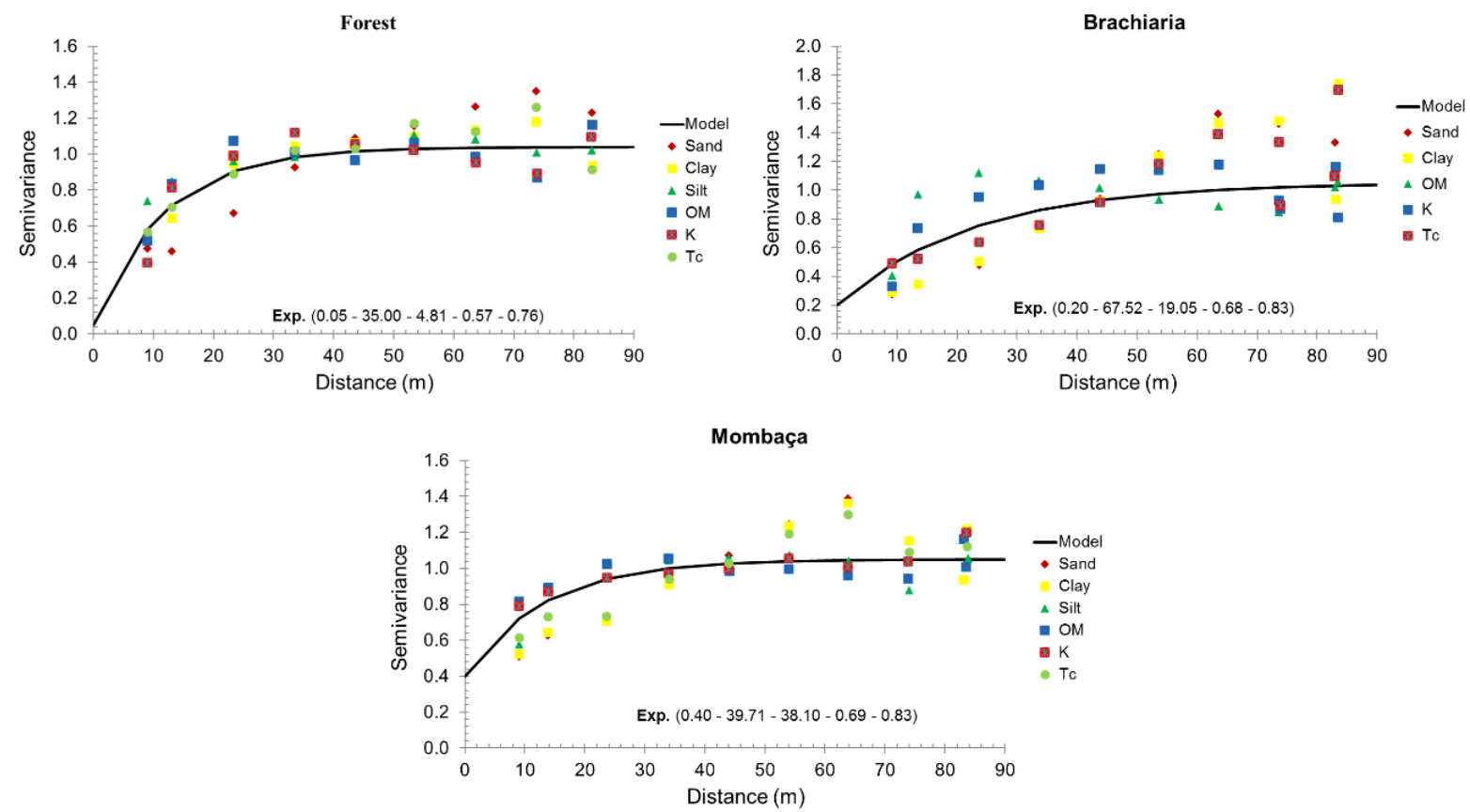

Figure 9. Scaled semivariograms for the environments studied in Porto Velho, Rondônia. The values in parentheses indicate respectively: nugget effect $\left(C_{0}\right)$, range $(a)$, Degree of Spatial Dependence (DSD\%), coefficient of determination $\left(\mathrm{R}^{2}\right)$ and cross-validation $(\mathrm{C}-\mathrm{V})$.

The areas presented range values (a) ranging from 35.00 to $67.52 \mathrm{~m}$, with the highest value being found for the brachiaria area and the lowest value in the native forest area. In relation to $\mathrm{DSD} \%$, the forest and brachiaria area showed variables with strong spatial dependence. In contrast, the mombaça grass area showed moderate spatial dependence (Cambardella et al., 1994).

The factor analysis showed significant results $(\mathrm{KMO}=0.772 ; \mathrm{p}<0.05$, for the Barlett sphericity test) for the variables in the evaluated areas, showing suitability for the construction of the Principal Components (Figure 10).

In the principal component analysis (PCA), with the variables with the highest scores, two main components were extracted, which could explain the total variability of the data for the 0.0-0.2 $\mathrm{m}$ depth, in which the studied environments were influenced by the high levels of sand and clay, which interfere with soil compaction and OM accumulation (Table 3 and Figure 10).

However, each area had a well-distributed score distribution within the factorial plane, 
discriminating the specific characteristics presented by the type of management adopted in each studied area.

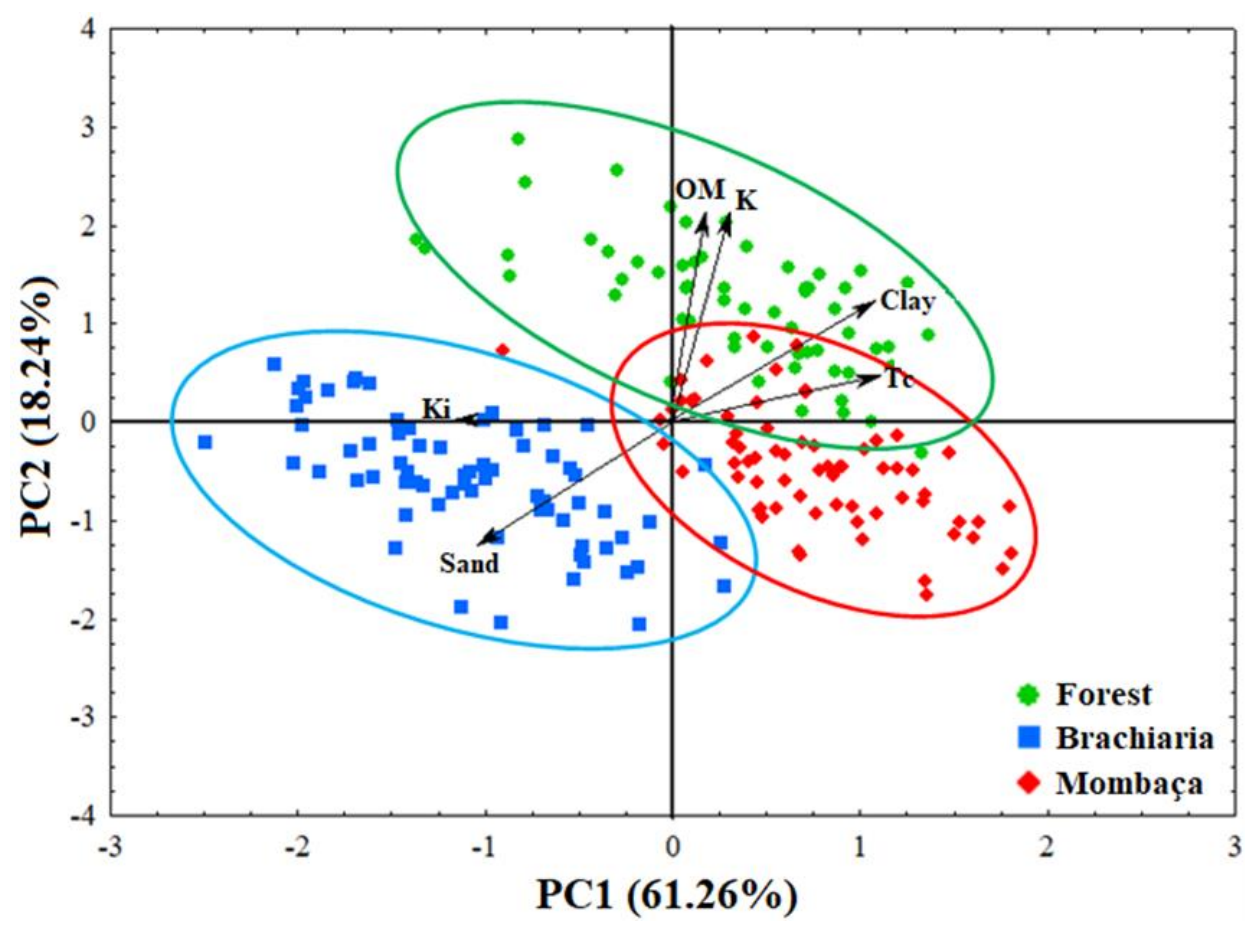

Figure 10. Principal component analysis of soil attributes at $0.0-0.2 \mathrm{~m}$ depth in pastures and forest areas in the municipality of Porto Velho, RO.

Table 3. Correlation between each principal component with soil texture and erodibility.

\begin{tabular}{|c|c|c|c|}
\hline \multirow{2}{*}{ Attributes } & \multirow{2}{*}{ Common Variation } & \multicolumn{2}{|c|}{ Factors } \\
\hline & & PC1 & PC2 \\
\hline Clay & 0.89 & $0.77 *$ & 0.52 \\
\hline Sand & 0.89 & $-0.73 *$ & -0.56 \\
\hline $\mathrm{OM}$ & 0.60 & 0.12 & $0.91 *$ \\
\hline $\mathrm{K}$ & 0.67 & 0.22 & $0.90 *$ \\
\hline $\mathrm{K}_{\mathrm{i} \text { wepp }}$ & 0.34 & $-0.82 *$ & -0.01 \\
\hline $\mathrm{T}_{\mathrm{c} \text { wepp }}$ & 0.42 & $0.78 *$ & 0.18 \\
\hline \multicolumn{2}{|c|}{ Explanatory Variance } & 61.26 & 18.24 \\
\hline
\end{tabular}

\section{DISCUSSION}

Studies highlight that asymmetry and kurtosis are indicators of data distribution; however, they are more sensitive to extreme values than the mean and median, and such values close to zero indicate greater normality of the data (Kamimura et al., 2013; Alho et al., 2016), with symmetrical values or not, the ideal is that these values are close to the central zero value (Cortez et al., 2011). For kurtosis, values of - 0.03 to 1.92 were observed; these values should preferably be null, however values between -2 to +2 are acceptable (Negreiros Neto et al., 2014).

According to Oliveira et al. (2015a), the statistical measure of CV\% allows comparing the 
variability between samples of variables with different units; however, it does not allow analyzing the spatial variability of soil attributes. Considering that the CV\% indicates the variability of the data in relation to the mean, the smaller the value the more homogeneous the data set is, it is possible to evaluate the homogeneous condition for the results found in the present study.

According to Frogbrook et al. (2002), high values of CV\% can be considered as the first indicators of the existence of heterogeneity in the data. Thus, based on the CV\% values found, it was possible to state that the analyzed attributes presented low to medium variation for the studied areas, corroborating the results found by Cunha et al. (2017).

In general, analyzing the results of factor $\mathrm{K}$, it was observed that they were lower than the values of $5.21 \times 10^{-2} \mathrm{tha}^{-1} \mathrm{MJ}^{-1} \mathrm{~mm}^{-1}$ ha $\mathrm{h}$, found by Nunes et al. (2017) studying the application of the universal equation of soil losses in Argissolos in the southern region of Amazonas.

According to Castro et al. (2011), the K factor, can be classified into classes according to its potential, so that the authors adopt the following classifications: $\mathrm{K}<9.00 \times 10^{-3}$ (very low); $9.00 \times 10^{-3}<\mathrm{K} \leq 1.50 \times 10^{-2}$ (low); $1.50 \times 10^{-2}<\mathrm{K} \leq 3.00 \times 10^{-2}$ (mean); $3.00 \times 10^{-2}<\mathrm{K} \leq$ $4.50 \times 10^{-2}$ (high); $4.50 \times 10^{-2}<\mathrm{K} \leq 6.00 \times 10^{-2}$ (very high), and $\mathrm{K}>6.00 \times 10^{-2}$ (extremely high).

In this sense, taking into account that values found in the three areas studied ranged from 0.01 to $0.03 \mathrm{t} \mathrm{ha}^{-1} \mathrm{MJ}^{-1} \mathrm{~mm}^{-1}$ ha, it was possible to classify the areas in the following classes: low erodibility for the brachiaria area; and medium erodibility for mombaça grass and forest.

However, the forest area is located in areas considered to be flatter, allowing less conditions for sediment losses caused by water erosion, since it is the main form of degradation of Brazilian soils, caused by rain drops and runoff, which carry suspended soil particles, nutrients, organic matter and chemicals, causing serious damage to agricultural activities (Bertol et al., 2007).

Regarding $\mathrm{K}_{\mathrm{i} \text { wepp }}$ and $\mathrm{K}_{\mathrm{r} \text { wepp }}$, it was possible to observe that the brachiaria area had the highest value compared to the other areas studied, with a clear significant difference between them. In general, pasture areas, although well managed, are heterogeneous, and this problem can be even more accentuated when pastures are established in sloping areas (Artur et al., 2014).

When assessing the difference in texture for the three environments studied, it is observed that all areas at a depth of 0-0.2 m, showed a statistical difference (Table 1). When analyzing the fractions, it was observed that the sand fraction of the forest and pasture areas showed a significant difference between them by the Tukey test. The brachiaria area showed a medium texture, with high sand contents, while the forest and mombaça grass areas were clayey. The high levels of sand in the brachiaria area may be related to the topography of the respective areas, due to the flood of small particles of the mineral fraction (clay) and organic matter, which are transported by surface runoff. In general, studies highlight that the topography of the terrain has a strong influence on erosion losses, especially due to the degree of slope and the length of the ramp (Campos et al., 2008).

Range $(a)$ is a parameter of geostatistics that has served as a basis for sample planning, indicating the maximum distance at which the attribute is spatially correlated (Dalchiavon et al., 2012). Reflecting the degree of homogenization between the samples, the higher the value, the more homogeneous the phenomenon or process will be studied. Range values ranging from $22.80(\mathrm{OM})$ to $79.29 \mathrm{~m}$ (sand) were observed, followed by brachiaria from $20.69(\mathrm{OM})$ to 90.00 $\mathrm{m}$ (clay) and for mombaça grass $17.60(\mathrm{OM})$ at $90.00 \mathrm{~m}$ (clay). This means that all neighbors within this radius can be used to estimate values in closer spacing, and that all samples are correlated and dependent on each other at the same distance from each other.

The area with brachiaria showed higher values of range in relation to the other areas, indicating that the area of brachiaria has less variability and is more homogeneous. In contrast, the area with mombaça grass showed smaller values of range, indicating that this area has 
greater variability, thus being more heterogeneous. Thus, this greater variability in the area of mombaça grass may be related to the greater grazing intensity (Alencar et al., 2016).

The Degree of Spatial Dependence (DSD) presented values varying from 0.00 to $37.50 \%$ between the studied areas, presenting strong spatial dependence (DSD $<25 \%$ ) and moderate $(26 \%<\mathrm{DSD}<75 \%)$ (Cambardella et al., 1994), indicating that the studied variables are not randomly distributed in space (Cavalcante et al., 2011).

The mombaça grass area showed a strong DSD for most of the variables compared to the variables of the forest and brachiaria environments, showing that possibly the mombaça grass area is more influenced by the intrinsic properties of the soil linked to the formation factors (Cambardella et al., 1994).

However, the sand fraction of the forest area and the variable $\tau_{\mathrm{c} \text { wepp }}$ for brachiaria area, along with the variables silt, $\mathrm{K}$ and $\tau_{\mathrm{c} \text { wepp }}$ for mombaça grass, were shown to have a moderate spatial dependence $(26 \%<\mathrm{DSD}<75 \%)$. For the other variables, a strong degree of spatial dependence was found.

The semivariograms were adjusted to the exponential model for all areas studied except for the attribute OM, which presented the spherical model for brachiaria, mombaça and forest area (Figures 4, 5 and 6), and for the sand of the brachiaria area which best fit the Gaussian model (Figure 5). The choice of models was evaluated using the highest $\mathrm{R}^{2}$ value, corroborating with Faraco et al. (2008), in which they evaluated the exponential model for most variables, followed by the spherical and Gaussian model and excluding those that presented a pure nugget effect (PNE).

According to Isaaks and Srivastava (1989), spherical models describe soil properties with high spatial continuity, that is, less erratic over short distances. Studies by Aquino et al. (2015), evaluating forest and pasture areas, observed that the spherical and exponential models were also the ones that best fit for physical soil attributes.

Carvalho et al. (2010), in a study about spatial variability of the physical and chemical attributes of the soil, mention that the $\mathrm{R}^{2}$ and cross-validation are tools designed to evaluate alternative models of semivariograms that will perform kriging to predict values in places unsampled and to optimize sampling loops. The lowest values of the $\mathrm{R}^{2}$ obtained were found in factor $\mathrm{K}$ and $\mathrm{OM}$ in the three areas. But in general the values were high, allowing us to obtain maps of the spatial distribution of the attributes with quality.

Kriging maps allow the establishment of land-use and management criteria in isolation for each variable evaluated, making it possible to improve the use of the area, the nutrition of pastures (Alencar et al., 2016), with decreased production costs and quick and certain decision making, enabling greater productivity and also the conservation of the environment through less use of pesticides, in addition to providing more detailed and useful records of the productive area (Santos et al., 2017).

The K factor kriging maps showed smaller and uniform scores, indicating that soil losses, in general, occur more uniformly. Thus, the maps of the spatial distribution of the physical attributes are presented in Figures 7, 8 and 9, which allowed a greater understanding of the distribution of the analyzed areas. In this way, the study of the spatial distribution of the physical properties of the soil can be used to select indicators of groundwater storage and flow potential (Alvarenga et al., 2012) and to identify degraded pasture regions (Grego et al., 2012).

Through maps it is possible to observe spatial correlations between attributes, mainly those related to compaction. In general, it is possible to verify which attributes are most influenced by the relief. It is observed that the variables related to the texture suffer more changes due to the relief, that is, this occurs due to the microreliefs present in the areas, which condition the different flows of water and the soil particles from the highest parts to the lowest with it (Oliveira et al., 2013).

Burak et al. (2012) proved that the higher the PCA scores, the greater their contribution to 
positive correlations between the variables that make up each factor. In contrast, the $\mathrm{K}$ factor had lower scores, so the lower the scores, the greater the contribution to negative correlations.

The forest area showed most of the positive scores, while the pasture areas showed the most negative. According to Ribas and Vieira (2011), the objective of principal component analysis (PCA) is achieved when a relatively small number of extracted components have the ability to explain most of the variability in the original data. It allows us to qualitatively evaluate at the same time the interactions between the attributes of the soil. In general, these attribute values were normalized to the mean equal to zero (0) and the variance equal to one (1).

In detail, the first component explained $61.26 \%$ of the total variability of the data; such a component presented a percentage of explanation for attributes more focused on soil granulometric characteristics such as: sand, clay, $K_{i \text { wepp }}$ and $\tau_{\mathrm{c} \text { wepp. }}$. It was also observed that only clay, OM, K and $\tau_{\mathrm{c} \text { wepp }}$ correlated positively (Table 3 , Figure 10 ).

The mombaça grass area functions as an intermediate environment between the forest and the brachiaria, being closer to the forest environment (Figure 10). Thus, PC2 shows that brachiaria is discriminated by the highest sand content, and PC1 by $\mathrm{K}_{\mathrm{i} \text { wepp }}$. However, the area with mombaça grass showed intermediate levels in relation to the areas studied. In general, it was possible to attribute the highest levels of sand and the lowest levels of silt and clay in the pasture areas in relation to the forest, the greater intensity of removal of fine particles provided by the micro reliefs, and according to Oliveira et al. (2013), also to the conditioning of water flows (Oliveira et al., 2013), which are intensified by the low ground cover provided by pastures (Santos et al., 2018).

The second PC had an explanation percentage of $18.24 \%$ of the data variability, with characteristics more related to the condition of $\mathrm{OM}$ and factor $\mathrm{K}$ of the soil, and both attributes showed a positive correlation (Table 3 ). However, studies that address the soil organic matter fractions and their direct link to the $\mathrm{K}$ factor are still needed to understand why these two variables have a direct dependence relationship. In general, both PCs retained a percentage of the explained variance of $79.50 \%$ (Table 3 and Figure 10).

However, it was observed that all quadrants in each environment need differentiated management, more or less intensive, and thereby increase the efficiency of the use of natural resources, reducing the impact of agriculture on the environment and optimizing the economic costs for the agricultural system (Santos et al., 2017). Couto et al. (2016), evaluating through MANOVA different environments in the southwestern Amazon, observed that the pasture and forest environment do not differ statistically, corroborating the results found here. Oliveira $e t$ al. (2015b), evaluating soils under different uses in the southern region of Amazonas, also verified through multivariate analysis that forest and pasture environments do not differ from each other.

However, studies are needed in other regions, mainly in Rondônia, where there is a high livestock production, as it is still possible to increase production without deforesting the areas, only improving the productivity of soils with adequate management, aiming at improving economic, social and environmental aspects.

\section{CONCLUSION}

The high spatial variability of physical attributes in the environment with mombaça grass is attributed to the greater intensity of grazing and animal trampling.

The forest area represents most of the positive scores obtained in the principal component analysis, while the pasture areas the majority of the negative scores, indicating that the OM in the forest is correlated with the acidity components, differently from the correlations found for the pastures.

The $\mathrm{K}$ factor presented low variability for pasture area compared to forest area, indicating a good homogeneity of the area in addition to a good representativeness of the samplings carried 
out.

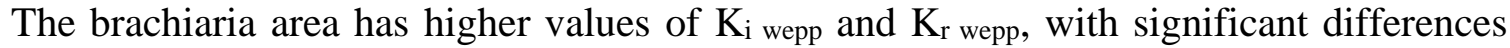
between the other areas. However, the forest and pasture environments differed in terms of soil erodibility, where the area with mombaça grass was intermediate between brachiaria and forest.

\section{REFERENCES}

ADAMY, A. (org.). Geodiversidade do estado de Rondônia. São Paulo: CPRM, 2010. 337 p.

ALENCAR, N. M.; MELO J. C.; SANTOS, A. C.; CUNHA, O. F. R.; PAULA NETO, J. J. Distribuição espacial das propriedades do solo, produção do capim-marandu com a intensidade de pastejo. Revista Engenharia na Agricultura-Reveng, v. 24, n. 4, p. 338349, 2016. https://doi.org/10.13083/reveng.v24i4.602

ALHO, L. C.; CAMPOS, M. C. C.; MANTOVANELli, B. C.; SILVA, D. M. P.; SOUZA, Z. M.; CUNHA, J. M. et al. Physical and geospatial attributes of inceptisols and ultisols under native vegetation in Humaitá, AM, Brazil. Bioscience Journal, v. 32, n. 2, p. 422 430, 2016.

AlvarenGA, C. C.; MEllo, C. R. D.; Mello, J. M. D.; SILVA, A. M. D.; CURI, N. Índice de qualidade do solo associado à recarga de água subterrânea (IQSRA) na bacia hidrográfica do Alto Rio Grande, MG. Revista Brasileira de Ciência do Solo, v. 36, n. 5, p. 1608-1619, 2012. https://doi.org/10.1590/S0100-06832012000500025

ALVARES, C. A.; STAPE, J. L.; SENTELHAS, P. C.; GONÇALVES, J. L. M.; SPAROVEK, G. Köppen's climate classification map for Brazil. Meteorologische Zeitschrift, v. 22, n. 6, p. 711-728, 2013. https://dx.doi.org/10.1127/0941-2948/2013/0507

AMORIM, R. S. S.; SILVA, D. D.; PRUSKI, F. F.; MATOS, A. T. Avaliação do desempenho dos modelos de predição da erosão hídrica USLE, RUSLE e WEPP para diferentes condições edafoclimáticas do Brasil. Engenharia Agrícola, v. 30, n. 6, p. 1046-1049, 2010. https://doi.org/10.1590/S0100-69162010000600006

AQUINO, R. E.; CAMPOS, M. C. C.; MARQUES JUNIOR, J.; OLIVEIRA, I. A.; TEIXEIRA, D. D. B.; CUNHA, J. M. Use of scaled semivariograms in the planning sample of soil physical properties in southern Amazonas, Brazil. Revista Brasileira de Ciência do Solo, v. 39, n. 1, p. 21-30, 2015. https://doi.org/10.1590/01000683rbcs20150524

ARTUR, A. G.; OLIVEIRA, D. P.; COSTA, M. C.; ROMERO, R. E.; SILVA, M. V.; FERREIRA, T. O. Variabilidade espacial dos atributos químicos do solo, associada ao microrrelevo. Revista Brasileira de Engenharia Agrícola e Ambiental, v. 18, n. 2, p. 141-149, 2014. https://doi.org/10.1590/S1415-43662014000200003

ASSUNÇÃO, S. A.; PEREIRA, M. G.; ROSSET, J. S.; BERBARA, R. L. L.; GARCÍA, A. C. Carbon input and the structural quality of soil organic matter as a function of agricultural management in a tropical climate region of Brazil. Science of the Total Environment, v. 658, p. 901-911, 2019. https://doi.org/10.1016/j.scitotenv.2018.12.271

AZEVEDO, E. C. Uso da Geoestatística e de recursos de geoprocessamento no diagnóstico da degradação de um solo argiloso sob pastagem no estado de Mato Grosso. 2004. 141f. Tese (Doutorado) - Faculdade de Engenharia Agrícola Universidade Estadual de Campinas, Campinas, 2004. 
BERTOL, I.; COGO, N. P.; SCHICK, J.; GUDAGNIN, J. C.; AMARAL, A. J. Aspectos financeiros relacionados às perdas de nutrientes por erosão hídrica em diferentes sistemas de manejo do solo. Revista Brasileira de Ciência do Solo, v. 31, n. 1, p. 133-142, 2007.

BERTONI, J.; LOMBARDI NETO, F. Conservação do Solo. São Paulo: Ícone, v. 4, 1999.

BURAK, D. L.; PASSOS, R. R.; ANDRADE, F. V. Variabilidade espacial de atributos químicos do solo sob cafeeiro Conilon: relação com textura, matéria orgânica e relevo. Bragantia, v. 71, n. 4, p. 538-547, 2012. https://doi.org/10.1590/S000687052012000400012

BURAK, D. L.; PASSOS, R. R.; SARNAGLIA, S. A. Utilização da análise multivariada na avaliação de parâmetros geomorfológicos e atributos físicos do solo. Enciclopédia Biosfera, v. 6, n. 9, p. 1-11, 2010.

CAMBARDELLA, C. A.; MOORMAN, T. B.; NOVAK, J. M.; PARKIN, T. B.; KARLEN, D. L.; TURCO, R. F. et al. Field-scale variability of soil properties in Central Iowa. Soil Science Society of America Journal, v. 58, p. 1501-11, 1994. https://doi.org/10.2136/sssaj1994.03615995005800050033x

CAMPOS, M. C. C.; MARQUES JÚNIOR, J. ; MARTINS FILHO, M. V. ; PEREIRA, G. T. ; SOUZA, Z. M.; BARBIERI, D. M. Variação espacial da perda de solo por erosão em diferentes superfícies geomórficas. Ciência Rural, v. 38, n. 9, p. 2485-2492, 2008. https://doi.org/10.1590/S0103-84782008000900011

CARVALHO, S. R. L.; VILAS BOAS, G. S.; FADIGAS, F. S. Variabilidade espacial de atributos físicos e químicos em solos originados nos sedimentos da formação barreiras. Cadernos de Geociências, v. 7, n. 2, 2010.

CASTRO, W. J.; LEMKE-DE-CASTRO, M. L.; LIMA, J. O.; OLIVEIRA, F. C.; RODRIGUES, C.; FIGUEIREDO, C. C. Erodibilidade de solos do cerrado goiano. Revista em Agronegócios e Meio Ambiente, v. 4, n. 2, p. 305-320, 2011. https://doi.org/10.17765/2176-9168.2011v4n2p\%25p

CAVAlCANTE, E. G. S.; ALVES, M. C.; SOUZA, Z. M.; PEREIRA, G.T. Variabilidade espacial de atributos físicos do solo sob diferentes usos e manejos. Revista Brasileira de Engenharia Agrícola Ambiental, v. 15, n. 3, p. 237-243, 2011. https://doi.org/10.1590/S1415-43662011000300003

CEDDIA, M. B.; VIEIRA, S. R.; VILLELA, A. L. O.; MOTA, L. S.; ANJOS, L. H. C.; CARVALHO, D. F. Topography and spatial variability of soil physical properties. Scientia Agricola, v. 66, p. 338-352, 2009. https://doi.org/10.1590/S010390162009000300009

CORTEZ, J. W. ALVES, A. D. S.; MOURA, M. R. D.; OLSZEVSKI, N.; NAGAHAMA, H. J. Atributos físicos do Argissolo Amarelo do semiárido nordestino sob sistemas de preparo. Revista Brasileira de Ciência do Solo, v. 35, n. 4, p. 1207-1216, 2011.

COUTO, W. H.; ANJOS, L. H. C.; WADT, P. G. S.; PEREIRA, M. G. Atributos edáficos e resistência a penetração em áreas de sistemas agroflorestais no sudoeste amazônico. Ciência Florestal, v. 26, n. 3, p. 811-823, 2016. https://doi.org/10.5902/1980509824210

CUNHA, J. M.; GAIO, D. C.; CAMPOS, M. C. C.; SOARES, M. D. R; SILVA, D. M. P; LIMA, A. F. L. Atributos físicos e estoque de carbono do solo em áreas de Terra Preta Arqueológica da Amazônia. Revista Ambiente \& Água, v. 12, n. 2, p. 263-281, 2017. https://doi.org/10.4136/ambi-agua. 1890 
DALCHIAVON, F. C.; CARVALHO, M. P.; ANDREOTTI, M.; MONTANARI, R. Variabilidade espacial de atributos da fertilidade de um Latossolo Vermelho Distroférrico sob sistema plantio direto. Revista Ciência Agronômica, v. 43, n. 3, p. 453-461, 2012.

DEMARCHI, J. C.; PIROLI, E. L.; ZIMBACK, C. R. L. Estimativa de perda de solos por erosão na bacia hidrográfica do Ribeirão das Perobas (SP) nos anos 1962 e 2011. Raega - O Espaço Geográfico em Análise, v. 46, n. 1, p. 110-131, 2019. http://dx.doi.org/10.5380/raega.v46i1.56746

DENARDIN, J. E. Erodibilidade de solo estimada por meio de parâmetros físicos e químicos. Tese (Doutorado) - Escola Superior de Agricultura Luiz de Queiroz, p. 113, 1990.

DIAS, F. P. M.; HÜBNER, R.; NUNES, F. J.; LEANDRO, W. M.; XAVIER. F. A. S. Effects of land-use change on chemical attributes of a Ferralsol in Brazilian Cerrado. Catena, v. 177, p. 180-188, 2019. https://doi.org/10.1016/j.catena.2019.02.016

FARACO, M. A.; URIBE-OPAZO, M. A.; SILVA, E. A. A.; JOHANN, J. A.; BORSSOI, J. A. Seleção de modelos de variabilidade espacial para elaboração de mapas temáticos de atributos físicos do solo e produtividade da soja. Revista Brasileira de Ciência do Solo, v. 32, n. 2, p. 463-476, 2008.

FLANAGAN, D. C.; LIVINGSTON, S. J. (eds.). USDA - Water erosion prediction project: WEEP user summary. West Lafayette: National Soil Research Laboratory \& USDA, 1995. p. 25-26.

FRANZLUEBBERS, A. J.; STUEDEMANN, J. A.; FRANKLIN, D. H. Water infiltration and surface-soil structural properties as influenced by animal traffic in the Southern Piedmont USA. Renewable Agriculture and Food Systems, v. 27, p. 256-265, 2011. https://doi.org/10.1017/S1742170511000378

FROGBROOK, Z. L.; OLIVER, M. A.; SALAHI, M.; ELLIS, R. H. Exploring the spatial relations between cereal yield and soil chemical properties and the implications for sampling. Soil Use and Management, v. 18, n. 1, p. 1-9, 2002. https://doi.org/10.1111/j.1475-2743.2002.tb00043.x

GOLDEN SOFTWARE INC. Surfer for Windows, Release 13.0: Contouring and 3D surface mapping for scientist's engineers, user's guide. 1999.

GUIMARÃES, E. C. Variabilidade espacial da umidade e da densidade do solo em um Latossolo Roxo. 1993. 57f. Dissertação (Mestrado) - Campinas: Universidade de Campinas. 1993.

GREGO, C. R.; RODRIGUES, C. A. G.; NOGUEIRA, S. F.; GIMENES, F. M. A.; OLIVEIRA, A. D.; ALMEIDA, C. G. F. D. et al. Variabilidade espacial do solo e da biomassa epígea de pastagem, identificada por meio de geoestatística. Pesquisa Agropecuária Brasileira, v. 47, n. 9, p. 1404-1412, 2012. https://doi.org/10.1590/S0100-204X2012000900026

KAMIMURA, K. M., SANTOS, G. R. D., OLIVEIRA, M. S. D., DIAS JUNIOR, M. D. S., \& GUIMARÃES, P. T. G. Variabilidade espacial de atributos físicos de um Latossolo Vermelho-Amarelo, sob lavoura cafeeira. Revista Brasileira de Ciência do Solo, v. 37 , n. 2, p. 877-88, 2013.

IBGE. Mapa de Vegetação do Brasil. Escala: 1:5,000,000. Instituto Brasileiro de Geografia e Estatística - IBGE. 2004. 
IBM. SPSS Statistics 21.0. 2017.

ISAAKS, E. H.; SRIVASTAVA, R. M. An introduction to applied geostatistics. Oxford: Oxford University Press, 1989.

MACEDO, R. S.; TEIXEIRA, W. G.; ENCINAS, O. C.; SOUZA, A. C. G.; MARTINS, G. C.; ROSSI, L. M. B. Determinação do fator erodibilidade de diferentes classes de solo do estado do Amazonas (métodos indiretos) e de um Cambissolo Háplico (método direto) na Província Petrolífera de Urucu, Coari - AM. In: REUNIÃO CIENTIFICA DA REDE CTPETRO AMAZÔNIA, 3., 4 a 5de nov. 2010, Manaus. Anais[...] Brasília: Embrapa, 2010.

MARQUES, J. J. G. S. M.; CURI, N.; LIMA, J. M.; FERREIRA, M. M.; SILVA, M. L. N.; FERREIRA, D. F. Estimativa da erodibilidade a partir de atributos de solos com horizonte B textural no Brasil. Revista Brasileira de Ciência do Solo, v. 21, p. 457-465, 1997.

MINGOTI, S. A. Análise de dados através de métodos de estatística multivariada. Belo Horizonte: UFMG, 2007. 295 p.

MORGAN, R. P. C. Soil Erosion and Conservation. Essex: Longman; 3, 1995.

NEGREIROS NETO, J. V.; SANTOS, A. C.; GUARNIERI, A.; SOUZA, D. J. A. T.; DARONCH, D. J.; DOTTO, M. A. et al. Variabilidade espacial de atributos físicoquímicos de um Latossolo Vermelho-Amarelo distrófico em sistema plantio direto. Semina: Ciências Agrárias, v. 35, n. 1, p. 193-204, 2014. https://dx.doi.org/10.5433/1679-0359.2014v35n1p193

NUNES, J. G.; CAMPOS, M. C. C.; NUNES, J. C.; MANTOVANELLI, B. C.; CUNHA, J.M.; SOARES, M. D. R. Aplicação da equação universal de perdas de solo na região sul do Amazonas. Revista da Universidade Vale do Rio Verde, v. 15, n. 2, p. 548-557, 2017. http://dx.doi.org/10.5892/ruvrd.v15i2.2991

OLIVEIRA, I. A.; MARQUES JUNIOR, J.; CAMPOS, M. C. C.; AQUINO, R. E.; FREITAS, L. D.; SIQUEIRA, D. S. et al. Variabilidade espacial e densidade amostral da suscetibilidade magnética e dos atributos de Argissolos da Região de Manicoré, AM. Revista Brasileira de Ciência do Solo, v. 39, n. 3, p. 668-681, 2015a. https://doi.org/10.1590/01000683rbcs20140496

OLIVEIRA, I. A.; CAMPOS, M. C. C.; MARQUES JUNIOR, J.; AQUINO, R. E.; TEIXEIRA, D. D. B.; SILVA, D. M. P. Use of scaled semivariograms in the planning sample of soil chemical properties in Southern Amazonas, Brazil. Revista Brasileira de Ciência do Solo, v. 39, n. 1, p. 31-39, 2015b. https://doi.org/10.1590/01000683rbcs20150525

OLIVEIRA, D. P.; FERREIRA, T. O.; ROMERO, R. E.; FARIAS, P. R. S.; COSTA, M. C. G. Microrrelevo e a distribuição de frações granulométricas em Cambissolos de origem calcária. Revista Ciência Agronômica, v. 44, n. 4, p. 676-684, 2013. https://doi.org/10.1590/S1806-66902013000400003

PERIGOLO, N. A.; MEDEIROS, M. B.; SIMON, M. F. Vegetation types of the upper Madeira River in Rondônia, Brazil. Brittonia, v. 69, n. 4, p. 423-446, 2017. https://doi.org/10.1007/s12228-017-9505-1

RIBAS, J. R.; VIEIRA, P. R. C. Análise Multivariada com o uso do SPSS. São Paulo: Ciência Moderna, 2011. 272 p. 
ROBERTSON, G. P. GS ${ }^{+}$: Geostatistics for the environmental sciences - GS ${ }^{+}$User's Guide. Plainwell: Gamma Design Software. 2004. 152 p.

SÁ, M. A. C.; LIMA, J. M.; CURI, N.; MASSAROTO, J. A.; SÁ, J. J. G.; MARQUES. M. Estimativa da erodibilidade pela desagregação por ultra - som e atributos de solos com horizonte B textural. Pesquisa Agropecuária Brasileira, v. 39, n. 7, p. 691-699, 2004. https://doi.org/10.1590/S0100-204X2004000700011

SANTOS, K. E. L.; BERNARDI, A. D. C.; BETTIOL, G. M.; CRESTANA, S. Geoestatística e geoprocessamento na tomada de decisão do uso de insumos em uma pastagem. Brazilian Journal of Biosystems Engineering, v. 11, n. 3, p. 294-307, 2017.

SANTOS, E. A. N.; CAMPOS, M. C. C.; CUNHA, J. M.; SOUZA, F. G.; WADT; P. G. S.; PINHEIRO, E. N.; Freitas, L. Gypsum, soil scarification and succession planting as alternatives to mitigate compaction of dystrophic Red-Yellow Latosol. Journal of $\begin{array}{llllllll}\text { Agricultural } & \text { Science, } & \text { v. } & 10, & \text { n. } & 8, & \text { p. } & \text { 277-285, }\end{array}$ https://doi.org/10.5539/jas.v10n8p277

SENA, M. M.; FRIGHETTO, R. T. S.; VALARINI, P. J.; TOKESHI, H.; POPPI, R. J. Discrimination of management effects on soil parameters by using principal component analysis: a multivariate analysis case study. Soil \& Tillage Research, v. 67, p. 171-181, 2002. https://doi.org/10.1016/S0167-1987(02)00063-6

SILVA, M. O.; FREIRE, M. B. G. S.; MENDES, A. M. S.; FREIRE, F. J.; CAMPOS, M. C. C.; AMORIM, L. B. Discriminação de diferentes classes de solos irrigados com águas salinas, na região de Mossoró, RN, com o uso de análise multivariada. Ambiência, v. 6, n. 2, p. 261-270, 2010.

SILVA NETO, S. P.; SANTOS, A. C.; LIMA LEITE, R. L.; DIM, V. P.; NEVES NETO, D. N.; SILVA, J. E. C. Variação espacial do teor de matéria orgânica do solo e produção de gramínea em pastagens de capim-marandu. Bioscience Journal, v. 28, n. 1, p. 41-53, 2012.

SOARES, M. D. R.; CAMPOS, M. C. C.; OLIVEIRA, I. A.; CUNHA, J. M.; SANTOS, L. A. C.; FONSECA, J. S. et al. Atributos físicos do solo em áreas sob diferentes sistemas de usos na região de Manicoré, AM. Revista Ciência Agraria, v. 59, n. 1, p. 9-15, 2016.

SCHLINDWEIN, J. A.; MARCOLAN, A. L.; FIORELI-PERIRA, E. C.; PEQUENO, P. L. L; MILITÃO, J. S. T. L. Solos de Rondônia: usos e perspectivas. Revista Brasileira de Ciências da Amazônia, v. 1, n. 1, p. 2013-2031, 2012.

STATSOFT INC. Statistica 7.0: data analysis software system. Tulsa, 2004.

TEIXEIRA, P. C.; DONAGEMA, G. K.; ADEMIR, F.; TEIXEIRA, W. G. Manual de métodos de análise de solo. 3. ed. Brasília: Embrapa, 2017. 573p.

WALKLEY, A.; BLACK, I. A. An examination of the degtjareff method for determining soil organic matter and a proposed modification of the chromic acid titration method. Soil Science, v. 37, n.1, p. 29-38, 1934.

WARRICK, A. W.; NIELSEN, D. R. Spatial variability of soil physical properties in the field, In: HILLEL, D. (ed.). Application of soil physics. New York: Academic Press, 1980. p. 319-344. 
WISCHMEIER, W. H.; JOHNSON, C. B.; CROSS, B. V. Soil erodibility monograph for farmland and construction sites. Journal of Soil and Water Conservation, v. 26, n. 5, p. 189-193, 1971.

YEOMANS, J. C.; BREMNER, J. M. A rapid and precise method for routine determination of organic carbon in soil. Communication in Soil Science and Plant Analysis, v. 19, n. 13, p. 1467-1476, 1988. https://doi.org/10.1080/00103628809368027

ZENERO, M. D. O.; GRIMALDIB, M.; COOPERA, M. Variability in soil shrinkage along forest and pasture toposequences in Amazonia. Geoderma, v. 338, p. 291-301, 2019. https://doi.org/10.1016/j.geoderma.2018.12.013 